\title{
Development and Evaluation of a Topical Anti-Inflammatory Preparation Containing Dodonaea polyandra Extract
}

Bradley S. Simpson ${ }^{1,2}$, Xianling Luo ${ }^{1,3}$, Jiping Wang ${ }^{3}$, Yunmei Song ${ }^{1}$, David. J Claudie ${ }^{4}$, Sanjay Garg ${ }^{1}$, Nicholas M. Smith $^{1}$, Ross A. McKinnon ${ }^{1,2}$, Susan J. Semple ${ }^{1}$

\begin{abstract}
${ }^{1}$ Sansom Institute for Health Research, University of South Australia, GPO, Adelaide, South Australia; ${ }^{2}$ Flinders Centre for Innovation in Cancer, Flinders University, GPO Box 2100, Adelaide, South Australia, ${ }^{3}$ Monash Institute of Pharmaceutical Sciences, Monash University, 381 Royal Parade, Parkville, Victoria, Australia; ${ }^{4}$ Chuulangun Aboriginal Corporation, PMB 30, Cairns Mail Centre, Cairns, Queensland, Australia.
\end{abstract}

Received, July 3, 2015; Revised, August 12, 2015; Accepted, September 16, 2015; Published, October 13, 2015.

\begin{abstract}
Purpose: We have previously reported that the Australian Northern Kaanju (Kuuku I'yu) medicinal plant Dodonaea polyandra has anti-inflammatory activity. This is attributed largely to the presence of clerodane diterpenoids contained within the leaf resin. We envisaged developing a topical preparation to treat indications relating to skin inflammation. However, it was unknown whether the resin could be incorporated into a suitable dosage form while retaining the therapeutic value demonstrated in previous work. Therefore, the following study was undertaken to assess parameters of safety and efficacy for a prototype formulation containing the leaf resin extracted from $D$. polyandra. Methods: Using the assessment criteria of optimum appearance, tactile feeling, spreadability and odour, 78 different formulations were developed. Formulation stability was assessed using a centrifugal test with preparations displaying phase separation further modified or re-formulated. A prototype formulation containing $5 \% \mathrm{w} / \mathrm{w}$ plant resin was selected and subjected to in vitro release studies. This was quantified through HPLC analysis using two major bioactive diterpenoids as reference. The prototype formulation was tested for efficacy in a TPA-induced acute murine skin inflammation model as well as a 3D human skin model for irritancy/toxicity (Epiderm ${ }^{\mathrm{TM}}$ ). Results: The prototype resin cream was a chartreuse-coloured homogenous semisolid preparation that was readily spreadable upon contact with skin with no sensation of tackiness, residual greasiness, or irritation. The optimized cream showed no phase separation after $30 \mathrm{~min}$ centrifugation at $825 \mathrm{~g}$. In the TPA-induced inflammation model, the resin formulation significantly reduced ear thickness and interleukin-1 beta levels in mouse ear tissue. The $5 \% \mathrm{w} / \mathrm{w}$ resin cream formulation showed no irritancy in a 3D human skin model. Conclusions: Our results demonstrate that bioactive resin from $D$. polyandra can be formulated into a stable and non-irritant semi-solid dosage form and reduce parameters of acute skin inflammation in vivo.
\end{abstract}

This article is open to POST-PUBLICATION REVIEW. Registered readers (see "For Readers") may comment by clicking on ABSTRACT on the issue's contents page.

\section{INTRODUCTION}

This study was undertaken as part of continued research aimed at establishing an efficacious and commercially viable product for use against inflammatory conditions of the skin, including eczema, psoriasis and dermatitis. These common skin inflammatory disorders have substantial impacts on quality of life for patients and costs to the healthcare system and society (1-3). While there are a range of anti-inflammatory drug therapies in existence the limitations of these therapies, particularly in terms of their side-effect profiles, has driven the search for new drug entities with novel mechanisms of action and improved safety profiles $(2,4)$.

Our pharmacological investigation of the medicinal plant Dodonaea polyandra Merr. \&
L.M. Perry (Sapindaceae) began as part a project initiated by the Chuulangun Aboriginal Corporation. This Corporation represents Traditional Owners of the Northern Kaanju (Kuuku I'yu) homelands centred on the Wenlock and Pascoe Rivers in Cape York Peninsula, Queensland, Australia. Traditional Owners are seeking to examine opportunities for development of their natural resources such as medicinal plants in a way that could contribute to economic development on their homelands. Particular Kuuku I'yu (Northern Kaanju) families involved in the project use Dodonaea polyandra as a medicine for relief of pain and inflammation in the mouth. The plant is used by breaking off one of the terminal branchlets (stems) with a leaf attached.

Corresponding Author: Susan J. Semple; Email address: susan.semple@unisa.edu.au 
The plant material is applied directly to the mouth to reduce pain and inflammation. In Australia, the natural distribution of $D$. polyandra is restricted to Cape York Peninsula, particularly on the east and north coast and off-shore islands (5). The plant also grows in the Western province of Papua New Guinea (5).

Initially we showed that crude ethanolic extracts of the leaves of the plant have significant anti-inflammatory activity in the 12-Otetradecanoylphorbol-13-acetate (TPA)-induced mouse ear oedema model for skin inflammation (6). In this model, thickening of skin tissue occurs which is indicative of a number of processes that occur during skin inflammation, including increased vascular permeability, swelling in the dermal layer, and proliferation of the epidermal cells (7). We subsequently showed that extracts of this plant species are rich in diterpenoid secondary metabolites of both the clerodane and labdane classes (8-10). In particular, two of the furanoclerodane diterpenoids, now designated polyandric acid (PA) A and B (Figure 1), were found to be the main active components of the plant extract, demonstrating potent antiinflammatory activity in the TPA-induced mouse ear oedema model (8). These compounds can be found in the leaf resin that forms a white powder on the leaf surface once dried.

In a subsequent study (10) focussed on the clerodane PAA we demonstrated that topical application of an ethanolic solution of the compound to mouse ear tissue significantly inhibited interleukin (IL)-1 $\beta$ production in the ear tissue in an acute TPA-induced inflammation model. Further, in a mouse model of chronic skin inflammation, a marked reduction in ear thickness, associated with significant reduction in myeloperoxidase accumulation (a measure of neutrophil infiltration), was observed. In order to better understand potential effects in human skin, treatment of primary neonatal human keratinocytes with PAA followed by activation with phorbol ester/ionomycin was studied, showing a significant reduction in secretion of IL-6 but not tumour necrosis factor (TNF)- $\alpha(10)$.

Studies on extracts of a more widely distributed medicinal Dodonaea species, Dodonaea viscosa, have also identified a furanoclerodane diterpenoid called hautriwaic acid as an active anti-inflammatory compound $(11,12)$. Recently, it has been shown that this compound inhibits inflammatory cytokine release in a mouse model of knee arthritis and reduces the concentration of pro-inflammatory cytokines IL$1 \beta$, IL- 6 , and TNF- $\alpha$ in the joint (12).

In this study we sought to develop and optimise topical formulations containing the leaf resin of $D$. polyandra that would display similar efficacy to resin delivered through an ethanol vehicle. The anti-inflammatory efficacy and toxicity of one prototype cream was evaluated using a TPA-induced acute mouse ear oedema model and a three-dimensional human skin model, respectively.

\section{MATERIALS AND METHODS}

\section{Materials and equipment}

Materials used included stearyl alcohol (Scharlan, Spain), Vaseline ${ }^{\circledR}$ (Chem-supply, Australia), Span 40 and 80 (Aldrich, USA), Tween 80 (Aldrich, USA), absolute ethanol (Chem-supply, Australia), Polychol 15 (CRODA, Australia) Carbopol 934P (Neveon, USA), liquid paraffin (Ajax Finechem, New Zealand), polyethylene glycol (PEG) 4000 (BDH, England), PEG 300 (Sigma, Germany), Cremophor EL, Pluronic F-127, methyl paraben, propyl paraben, and 12-O-tetradecanoylphorbol13-acetate (TPA) (Sigma, USA), acetone (Merck, Germany). For the HPLC mobile phase acetonitrile (HPLC grade) and formic acid (purity 98-100\%) were purchased from Merck (Germany). Additional formulation excipients are listed separately in supplementary information.
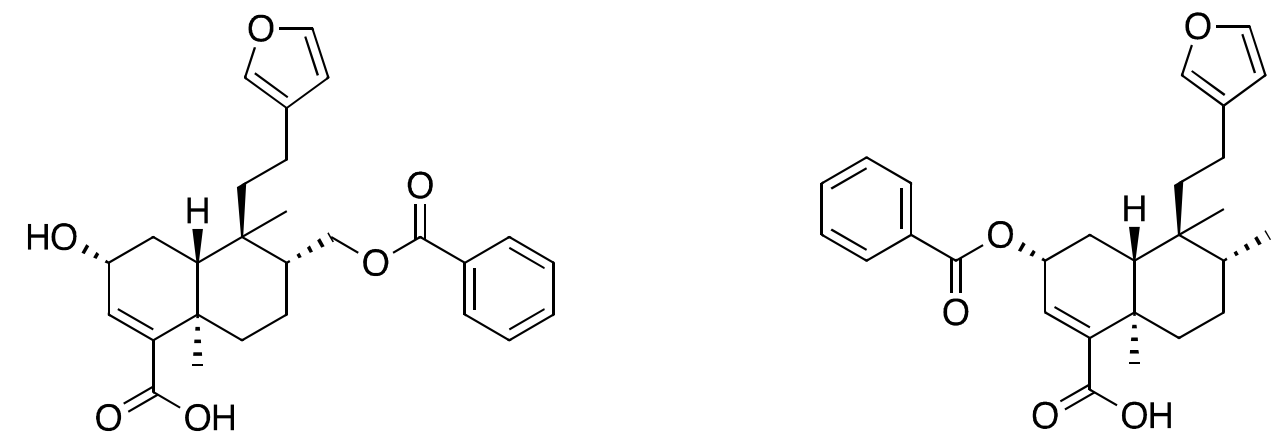

Figure 1. Chemical structures of polyandric acid A (left) and B (right). 
Equipment included a homogenizer (Ultra TURRAX ${ }^{\circledR}$ T25 basic, IKA Labortechnik), digital electronic micrometer $( \pm 0.001 \mathrm{~mm}$, Mitutoyo, Japan), Cyber Scan pH 1100 (Southern Cross, Science Pty Ltd, Australia), tissue processing machine (ASP300S, LEICA), tissue embedding machine (EG1160, LEICA), microtome (HM325, LEICA), tissue homogenizer (MICCRA D-1, ART-moderne Labortechnik, Germany), water bath (HI1210, LEICA), microscope (OLYMPUS BX 40F-3, Japan), centrifuge (Sigma 1-15, SIGMA Laborzentrifugen $\mathrm{GmbH}$ ), mechanical tumbler (Erweka AR400, Erweka Apparatebau GMBH, Germany) and rotary evaporator (Buchi Rotavap RII).

\section{Preparation of the resin extract and quantification of active clerodane diterpenoid compounds}

Leaf material from Dodonaea polyandra was collected in June 2011 by Northern Kaanju researchers on Kuuku I'yu Northern Kaanju homelands, Central Cape York Peninsula, Queensland, Australia. Voucher specimens and details of plant location $\left(13.04231^{\circ} \mathrm{S} 143.02617^{\circ}\right.$ E) were recorded and lodged at the South Australian State Herbarium (voucher specimen number AD268969). Plant material was allowed to air dry in the shade and packed into paper bags for transportation. The leaves were stored at -20 ${ }^{\circ} \mathrm{C}$ until extraction. Plant material, $100 \mathrm{~g}$, was placed in a mechanical tumbler for $2 \mathrm{~h}$ to loosen dried resin from the leaves. The resin powder was separated from leaves, which were subsequently transferred to a $2 \mathrm{~L}$ container and loose resin was washed from the leaves with a total of $450 \mathrm{~mL}$ absolute ethanol and combined with the first portion of the extract. The ethanolic extract was decanted and filtered in vacuo through Whatman No.1 filter paper (Whatman, UK) and concentrated using a rotary evaporator $\left(40-42^{\circ} \mathrm{C}\right)$. Dried extract was forced through a $450 \mu \mathrm{m}$ sieve to procure fine resin powder. In order to determine the content of active clerodane diterpenoid compounds in the extracted resin, a sample of the resin was analysed by HPLC.

\section{Resin properties}

The resin extract obtained was olive-green in colour and had a mild leafy odour. The resin possessed a granular texture and crystalline appearance. The resin was freely soluble in ethanol, although some crystalline matter was observed to precipitate upon standing. The resin was insoluble in aqueous solutions.
Quantification of active clerodane diterpenoid compounds by High Performance Liquid Chromatography (HPLC)

Analysis of active components was performed using a previously validated method (PAA: intra/inter-day accuracy $-0.66 /-1.32 \%$, intra/interday precision $2.59 / 4.01 \%$, linearity $r^{2}=0.9992$; PAB: intra/inter-day accuracy-0.48/-2.14\%, intra/inter-day precision $2.49 / 3.34 \%$, linearity $r^{2}=$ $0.9994)$ (13). The method was conducted using a Shimadzu LC-20AD with degasser (DGU-20A3) coupled with an auto-sampler (SIL-20A HT, 200 $\mu \mathrm{L}$ loop) and PDA detection SPD-M20A. Separations were carried out on Phenomenex Gemini C18 column with guard cartridge. The mobile phase consisted of acetonitrile $(65 \% \mathrm{v} / \mathrm{v})$, Milli-Q water (35\% v/v) and formic acid $(0.05 \%$ $\mathrm{v} / \mathrm{v}$ ), degassed prior to use. The mobile phase flow rate was $1.4 \mathrm{~mL} / \mathrm{min}$ with $30 \mathrm{~min}$ run time. The active components were detected using a wavelength of $225 \mathrm{~nm}$. Sample injection volume was $20 \mu \mathrm{L}$. Retention times for active components PAA and PAB were approximately 7 and $20 \mathrm{~min}$, respectively.

\section{Preparation of formulations and their assessment}

A series of semisolid formulations were used in the initial trial for formulations. Briefly, 78 semisolid formulations were designed and prepared. They were categorised into three series, including cream, gel and ointment-based formulations according to pharmaceutical nomenclature used by the CDER Data Standards Manual Definitions for Topical Dosage Forms (14). Full details of the different formulations tested are provided in the Supplementary Information (Tables S2 to S15). Creams (Supplementary Information Tables S2, $\mathrm{S} 3, \mathrm{~S} 7$ to S13 and S15) were classified into 10 types according to the application of different emulsifiers and surface active agents, including Tween, Span, Polychol and Cremophor. Gels (Supplementary Information Tables S4, S5 and S6) were classified into 3 types based on the gelling agents used, which were Carbopol, Polyethylene glycol (PEG) and Pluronic F-127. One ointment (Supplementary Information Table S14) was prepared, in which the major components were Vaseline ${ }^{\circledR}$ and liquid paraffin. During the formulation development phase, a range of conditions including temperature, ratio of excipients, the sequence of excipient addition and force and duration of homogenation were all investigated in order to produce the optimal product. 
Physical characteristics

All formulations listed in Supplementary Information tables S2 to S15 were evaluated using standard criteria for spreadability and acceptability. Spreadability of formulations was determined according to the criteria outlined in Table 1. Vehicles rating at " 0 " or " 1 " were considered to have adequate spreadability. Acceptability was determined with subjective assessment of appearance, tactile feel, texture and odour.

In practice, preparations with insoluble sediments, poor spreadability or unpleasant smell or tactile feel were further modified or reformulated. The $\mathrm{pH}$ of each formulation was also determined (Universal indicator $\mathrm{pH}$ 0-14, Merck).

\section{Centrifugation test}

All creams and the ointment (supplementary Tables S2, S3, S7 to S15) were subjected to centrifugation to assess accelerated deterioration based on the method by Anchisi et al. (15) with some modification. The preparations were centrifuged at $25{ }^{\circ} \mathrm{C}, 825 \mathrm{~g}$ for $30 \mathrm{~min}$. Gravitational stability was assessed as 'not stable' (phase separation occurs) or 'stable' (no phase separation). Preparations with signs of phase separation were further modified or re-formulated. Gravitational stability assessment was not applied to gels.

\section{Formulation of the prototype D. polyandra resin cream}

The resin cream contained $5 \% \mathrm{w} / \mathrm{w}$ of $D$. polyandra resin, the strength of which was recognised to achieve significant antiinflammatory effect based on unpublished preliminary studies. The optimised resin cream formulation was prepared with the following process. A $0.5 \mathrm{~g}$ portion of resin was dissolved in $1.2 \mathrm{~g}$ absolute ethanol before adding to the oil phase which consisted of $0.3 \mathrm{~g}$ Span 40, $1 \mathrm{~g}$ Polychol 15, $0.6 \mathrm{~g}$ Vaseline, $1.2 \mathrm{~g}$ stearyl alcohol, $18 \mathrm{mg}$ methyl paraben and $2 \mathrm{mg}$ propyl paraben melted at $80^{\circ} \mathrm{C}$. The aqueous phase $(5.2 \mathrm{~g}$ purified water) was heated to $80^{\circ} \mathrm{C}$ and slowly added to the oil phase under constant stirring. The mixture was homogenized for $2 \mathrm{~min}$ at $13,000 \mathrm{rpm}, 80^{\circ} \mathrm{C}$ (Ultra TURRAX $^{\circledR} \mathrm{T} 25$ basic). The cream was allowed to cool to room temperature with continuous homogenizing at $10,000 \mathrm{rpm}$. The characteristics of the cream were then investigated using the standard criteria for physical characteristics and deterioration (by accelerated centrifugal test described above).

\section{In vitro release test}

Franz diffusion cell was applied to quantify the release of active compounds from the formulation. The area for diffusion was $0.785 \mathrm{~cm}^{2}$, and the receptor chamber volume was $5.2 \pm 0.2 \mathrm{~mL}$. Hydrophilic polyvinylidene fluoride (PVDF) membranes $(0.45 \mu \mathrm{m}$, Pall Corporation) were placed between the donor chamber, which was loaded with $22 \pm 2 \mathrm{mg}$ test samples, and the receptor chamber, filled with water. The receptor fluid was kept at $32 \pm 1{ }^{\circ} \mathrm{C}$ by a water jacket and constantly stirred with a magnetic stirring bar. A $150 \mu \mathrm{L}$ volume of receptor fluid was drawn at 1, 2, 4, 6, and $8 \mathrm{~h}$ through a sampling port and was immediately replaced with $150 \mu \mathrm{L}$ of fresh water. As preliminary data indicated that the active compounds were sensitive to light, experiments were conducted in the dark. Active diterpenoid compounds PAA and $\mathrm{PAB}$ were determined by HPLC analysis as described above.

\section{Experimental animals}

Male Balb/C mice, 7-9 weeks of age, were housed in groups at a constant room temperature $(20 \pm$ $2^{\circ} \mathrm{C}$ ) and a $12 \mathrm{~h}$ normal day/night cycle (University of South Australia Animal Care Facility, Adelaide). They were kept in mouse cages and given free access to tap water and standard food. The mice were assigned randomly and kept in the laboratory for $48 \mathrm{~h}$ during which time their ear thickness and body weight were measured. Animal ethics approval was obtained for the experiments from the Institute for Medical and Veterinary Research (Adelaide) Animal Ethics Committee (Project \# 15/11).

Table 1. Criteria used to assess spreadability of formulations

\begin{tabular}{cl} 
Score & Description \\
\hline-2 & Formulation or vehicle appears as a solid state, which cannot be spread around the application site. \\
-1 & Formulation or vehicle has to be applied with force greater than normal to achieve a desirable spread. \\
0 & Formulation or vehicle displays good spreadability with desirable stay-on semisolid property. \\
1 & $\begin{array}{l}\text { Formulation or vehicle displays good spreadability with a slight tendency to flow over the skin } \\
\text { surface. }\end{array}$ \\
2 & Formulation or vehicle has low viscosity with high tendency to flow over the skin surface.
\end{tabular}




\section{TPA-induced mouse ear oedema model}

Anti-inflammatory activity was measured by a mouse ear oedema model using topically applied 12-O-tetradecanoylphorbol 13-acetate (TPA) to induce inflammation on mice ears as described previously (6). The initial baseline ear thicknesses were recorded by a digital micrometer $( \pm 0.001$ $\mathrm{mm})$. The micrometer was applied near the tip of the ear distal to the cartilaginous ridges and the thickness was recorded in $\mathrm{mm}$ with 3 repeated measures.

At time zero, $20 \mu \mathrm{L}$ TPA $(2.5 \mu \mathrm{g} / 20 \mu \mathrm{L} /$ ear $)$ dissolved in acetone was applied topically to the right ear; an equivalent volume of acetone was applied to the left ear as control. Meanwhile, mice allocated in solvent negative control and cream vehicle negative control groups were treated with $20 \mu \mathrm{L}$ acetone on both ears. Thirty minutes later, cream $(5 \% \mathrm{w} / \mathrm{w}$ resin), cream vehicle, resin solution (dissolved in absolute ethanol, $20 \mathrm{mg} / \mathrm{mL}$ ) and absolute ethanol were applied to both surfaces of the right ear either in a volume of $20 \mu \mathrm{L}$ for solutions or liquid preparations, or in a thin layer for semisolid preparations. The left ears of mice receiving cream or cream vehicle remained untreated. A non-treated control group received TPA in acetone and was used as a measure of maximum inflammation. Twenty microliters of absolute ethanol was applied on the left ears as solvent control. Ear thicknesses were measured $6 \mathrm{~h}$ after TPA application. Mice were euthanized by inhalation of isoflurane followed by cervical dislocation. After excision of the ears, punch biopsies $(5 \mathrm{~mm})$ of each ear (one biopsy per ear) were taken. Ear tissue was homogenized in $500 \mu \mathrm{L}$ of Tris- $\mathrm{HCl}(50 \mathrm{mM}, \mathrm{pH}$ 7.4)/EDTA (1 mM) buffer containing protease inhibitor cocktail (Sigma, cat. no. P8340). The homogenate was incubated on ice in the presence of $1 \%(\mathrm{v} / \mathrm{v})$ Triton $\mathrm{X}-100$ for $15 \mathrm{~min}$ and subsequently centrifuged at $4^{\circ} \mathrm{C}$ for $15 \mathrm{~min}$ at $9500 \mathrm{~g}$. The supernatant was removed and stored at $-80^{\circ} \mathrm{C}$ pending analysis by IL-1 $\beta$ ELISA.

\section{IL-1 $\beta$ assay}

The supernatant from ear tissue homogenates was thawed $30 \mathrm{~min}$ prior to assaying for the proinflammatory cytokine IL-1 $\beta$. The concentration of IL-1 $\beta$ was determined using a Mouse IL-1 $\beta$ Platinum ELISA kit according to the manufacturer's instructions (eBioscience, cat\# BMS6002).

\section{Histological analysis}

Ear samples were fixed in $10 \% \mathrm{v} / \mathrm{v}$ neutral buffered formalin overnight, then embedded in paraffin, sectioned and stained with haematoxylin and eosin (H\&E) based on the standard procedures. Slides were observed under a light microscope (OLYMPUS BX 40F-3, Japan). A representative area was selected and inflammatory severities were subsequently qualitatively assessed based on ear thickness and inflammatory cell infiltration, indicated by purple/black stained cells.

\section{Epiderm $^{\text {TM }}$ MTT viability test}

To provide an estimate of dermal irritation potential, the $5 \% \mathrm{w} / \mathrm{w}$ resin cream, and an equivalent cream formulation without resin (cream base) were prepared and submitted for testing for toxicity using a three-dimensional human skin model - the MatTek Epiderm ${ }^{\mathrm{TM}}$ MTT viability test. Epiderm $^{\mathrm{TM}}$ tissues consist of normal, humanderived epidermal keratinocytes cultured to form a multilayered and differentiated model of the human epidermis. The study was conducted by the contract research organization MB Research Laboratories, Spinnerstown, PA, USA (Project number 13-21604.19), according to standard Good Laboratory Practice (GLP) protocols (16). Briefly, EpiDerm $^{\mathrm{TM}}$ human skin tissues were obtained from MatTek Corporation (Ashland, MA, USA). Tissue samples were treated with the resin cream, cream base or positive control ( $1 \%$ Triton ${ }^{\circledR} \mathrm{X}-100$, MatTek). The cream samples, $100 \mu \mathrm{L}$, were applied undiluted to the top of each EpiDerm ${ }^{\mathrm{TM}}$ tissue. The treatment times were 1, 4 and 24 hours for the cream samples and 4 and 9 hours for the positive control. Cells were incubated at $37{ }^{\circ} \mathrm{C}$ in $5 \% \mathrm{CO}_{2}$. Negative controls (no treatment) samples were also tested. Each treatment with the cream or control was performed in duplicate.

Following the specified treatment periods the viability of the tissues was determined using a methylthiazole tetrazolium (MTT) uptake and reduction assay. Tissue samples rinsed with phosphate buffered saline (PBS) were transferred to a 24-well plate containing $300 \mu \mathrm{L}$ of an MTT solution sample $(1 \mathrm{mg} / \mathrm{mL}$ MTT in Dulbecco's Modified Eagle's Medium). The tissues were incubated with MTT for three hours after which each tissue was rinsed with PBS and treated overnight with $2 \mathrm{~mL}$ of isopropanol as an extractant. An aliquot of the extracted formazan was transferred to a microplate and the absorbance was measured at $540 \mathrm{~nm}$ with a reference wavelength of $690 \mathrm{~nm}$ ( $\mu$ Quant Plate Reader, BioTek instruments, Winooski, VT). The viability was expressed as a percentage of control values and the percent viability at each time point was used to determine an $\mathrm{ET}_{50}$ which represented the time point at which the tissue viability was reduced by 
$50 \%$ compared to the negative control tissues. The $\mathrm{ET}_{50}$ score was used to give an irritancy classification.

\section{STATISTICS}

Results are presented as mean \pm SEM and statistical significance between groups was determined by one-way analysis of variance (ANOVA) with Dunnett t-test post hoc analysis, where $\mathrm{p}$-values $<0.05$ were considered significant.

\section{RESULTS}

\section{Quantification of active compounds}

The content of active compounds PAA and PAB in the resin, as determined by HPLC is shown in Table 2. An HPLC chromatograph of the resin is shown in Figure 2.

\section{Characteristics of the resin cream}

The oil-in-water cream containing $5 \% \mathrm{w} / \mathrm{w}$ of the resin was a chartreuse-coloured homogenous semisolid preparation with light alcoholic odor. It was readily spread around upon contact with skin. No sensation of tackiness, residual greasiness, or irritation was detected after application. In addition, resin cream possessed the desired spreadability and $\mathrm{pH}$ value of $5.0-6.0$. The prototype cream containing $5 \% \mathrm{w} / \mathrm{w}$ resin showed no phase separation as observed after $30 \mathrm{~min}$ centrifugation at $825 \mathrm{~g}$.

\section{Drug release test}

The release profiles of PAA and PAB, the main active compounds of $D$. polyandra, from the $5 \%$ $\mathrm{w} / \mathrm{w}$ resin cream are presented in Figure 3.

Table 2. Content of PAA and PAB in the resin

\begin{tabular}{lll}
\hline & PAA & PAB \\
\hline Content in resin $($ mean $+/-$ SD) & $11.4+/-0.16 \mathrm{mg} / \mathrm{g}$ & $133.3+/-0.6 \mathrm{mg} / \mathrm{g}$ \\
\hline
\end{tabular}

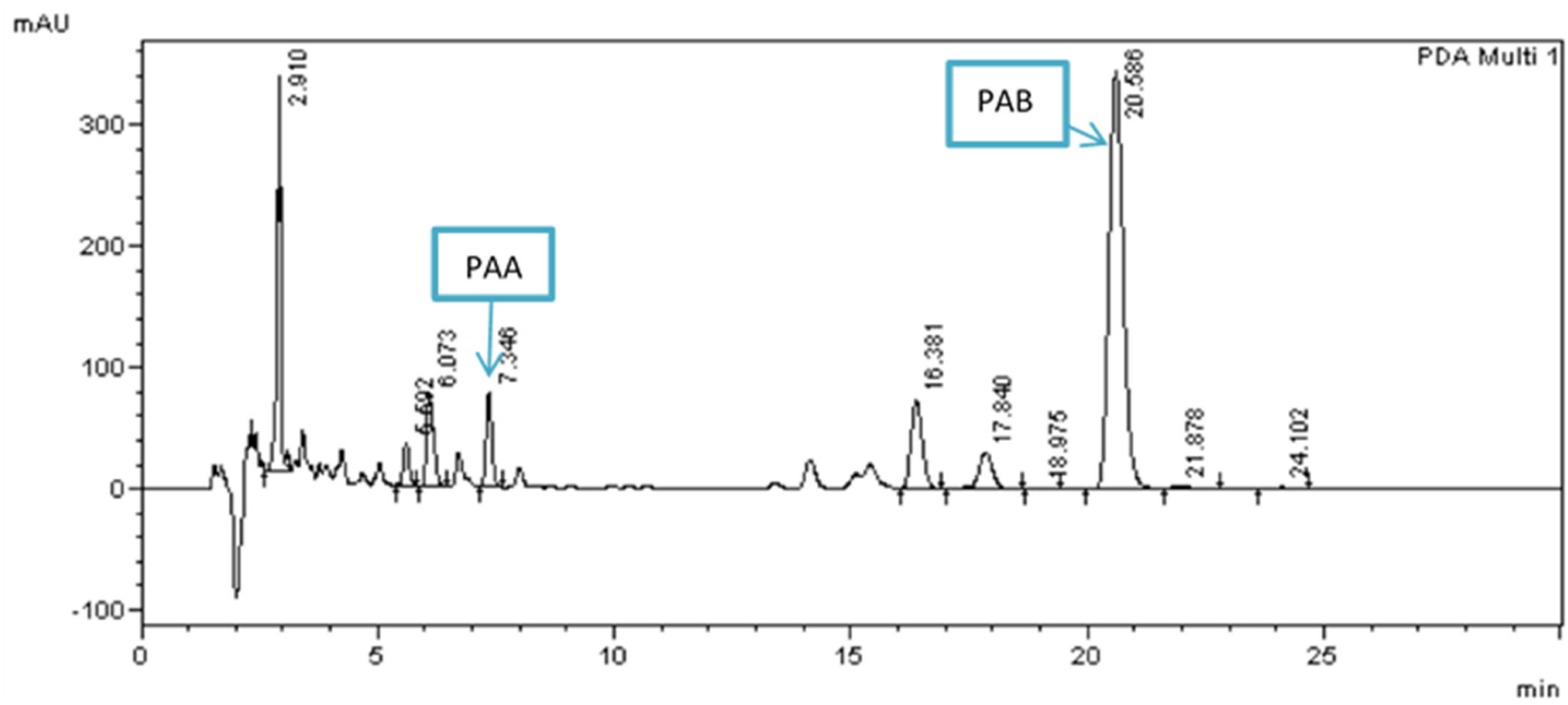

Figure 2. HPLC chromatograph of the Dodonaea polyandra resin used in the cream formulation. Chromatograph was run on a Shimadzu LC-20AD HPLC with PDA detection SPD-M20A. Separations were carried out on Phenomenex Gemini C18 column with guard cartridge with a mobile phase of acetonitrile $(65 \% \mathrm{v} / \mathrm{v})$, Milli-Q water $(35 \% \mathrm{v} / \mathrm{v})$ and formic acid $(0.05 \% \mathrm{v} / \mathrm{v})$. The mobile phase flow rate was $1.4 \mathrm{~mL} / \mathrm{min}$ with $30 \mathrm{~min}$ run time. The active components were detected using a wavelength of $225 \mathrm{~nm}$. Sample injection volume was $20 \mu \mathrm{L}$. Retention times for known active components $\mathrm{PAA}$ and $\mathrm{PAB}$ were 7.35 and 20.59 min, respectively. $\mathrm{PAA}=$ polyandric acid $\mathrm{A} ; \mathrm{PAB}=$ polyandric acid $\mathrm{B}$ 


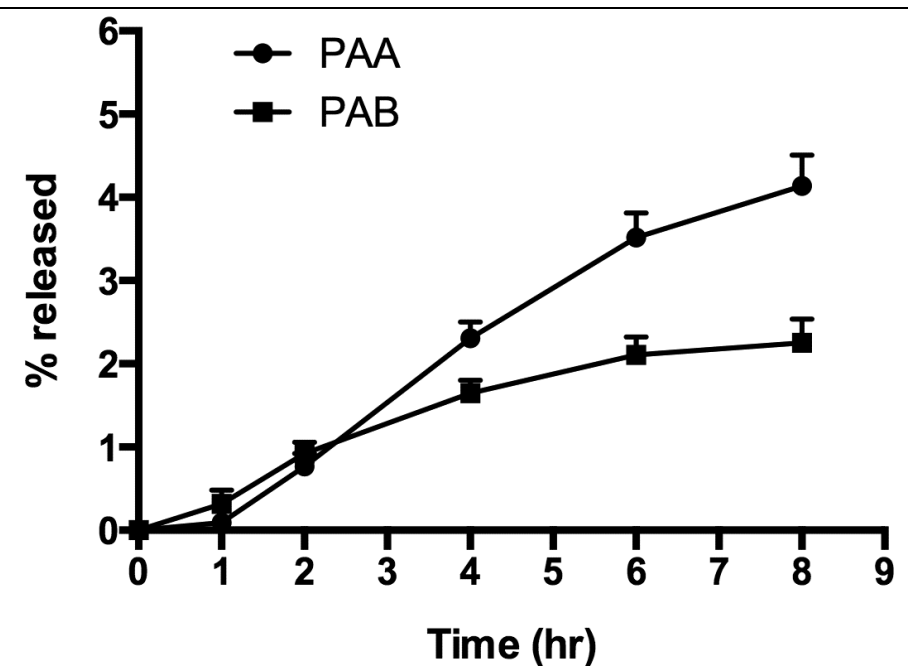

Figure 3. Release profiles of PAA and PAB from the resin cream $(5 \% \mathrm{w} / \mathrm{w})$ through polyvinylidene fluoride (PVDF) membranes using a Franz diffusion cell (Results are expressed as mean \pm SEM, $n=6$ )

The release test results showed after $8 \mathrm{~h}, 4.14 \pm$ $0.9 \%$ PAA and $2.25 \pm 0.7 \%$ PAB from resin cream were detected in receptor medium by HPLC.

\section{Anti-inflammatory effect of cream in vivo}

The anti-inflammatory effect of an optimized cream containing $5 \% \mathrm{w} / \mathrm{w}$ resin was tested in a TPA-induced acute mouse ear oedema model. We wanted to determine whether comparable efficacy could be achieved to that of resin delivered in an ethanol vehicle $(0.4 \mathrm{mg} / \mathrm{ear})$, as previously reported (6). Following $6 \mathrm{~h}$ of treatment, ear thickness difference measurements showed that the cream containing $5 \%$ resin significantly reduced ear oedema by $25 \%$ compared to TPA-only control $(p<0.01)$, while there was no statistical difference with the resin delivered in ethanol vehicle $(p>0.05)$. The cream formulation vehicle (i.e. without resin) did not show significant interference with changes in ear oedema (Figure 4).

The anti-inflammatory effects of treatments were also assessed by quantifying the proinflammatory cytokine IL-1 $\beta$ in ear tissue homogenates (Figure 5). The cream containing resin reduced IL- $1 \beta$ by $32 \%$ compared to TPA-only control $(p<0.001)$. Interestingly, there was no statistical difference between the $20 \mathrm{mg} / \mathrm{mL}$ resin solution $(0.4 \mathrm{mg} /$ ear $)$ and the TPA-only control, which is surprising given the reduction in oedema.

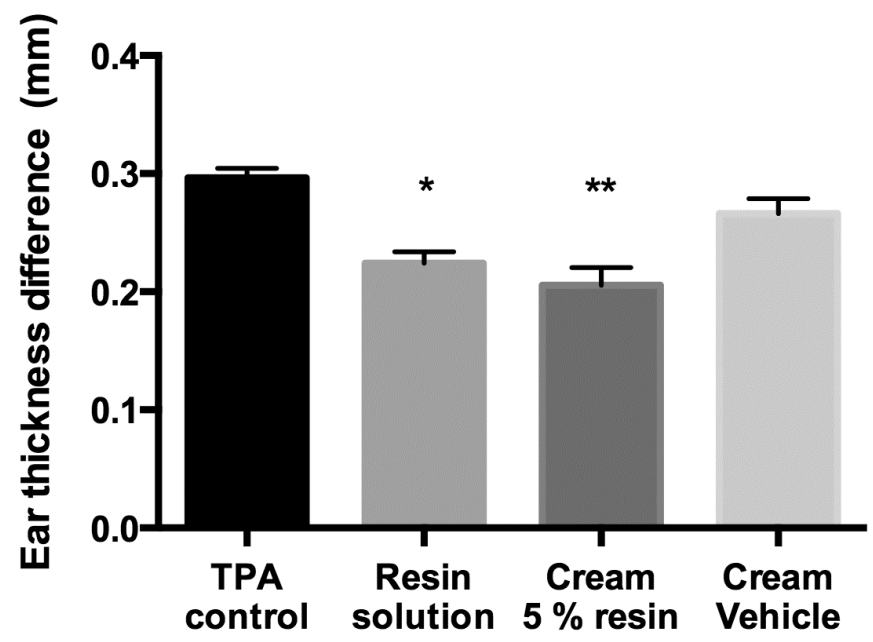

Figure 4. Effect of creams and resin solution on ear thickness in the TPA model. Increased ear thickness was represented by ear thickness difference (thickness of left ear - thickness of treated right ear). Measurement was conducted $6 \mathrm{~h}$ after the application of TPA. Each data represents Mean \pm SEM, $n=4$ mice per group; ${ }^{*} p<0.05$ and $* * p<0.01$ compared to TPA control. 


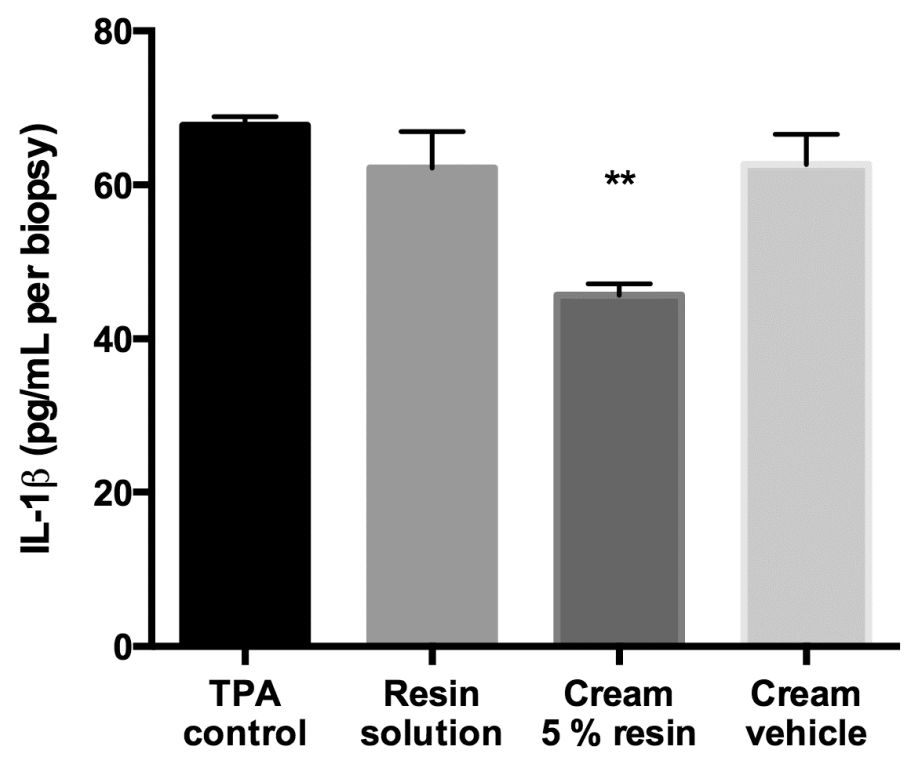

Figure 5. Effect of creams and resin solution on inflammatory cytokine IL-1 $\beta$ in ear tissue homogenates in the TPA model. Data shown are from biopsies of the right ears of mice $6 \mathrm{~h}$ after the application of TPA. Ear tissue was homogenized and the supernatant from ear tissue homogenates was assayed for the concentration of IL-1 $\beta$ using a Mouse IL-1 $\beta$ Platinum ELISA kit. Each data represents Mean \pm SEM, $n=4$ mice per group. ${ }^{* *} \mathrm{p}<0.01$ compared to TPA control.

\section{Mouse ear tissue histological study}

Mouse ear tissue samples were stained with hematoxylin and eosin (H\&E) to examine histology of skin sections (Figure 6). In comparison with an untreated ear (Figure 6A), application of TPA resulted in a considerable increase in ear thickness (edema) and substantial inflammatory cell infiltration (Figure 6B). Treatment with the cream base only (Figure 6C) resulted in only a small reduction in the ear thickness and inflammatory cell infiltration. By contrast, treatment with the cream containing $5 \%$ $\mathrm{w} / \mathrm{w}$ resin (Figure $6 \mathrm{D}$ ) reduced ear thickness and cell infiltration to an extent that was comparable to normal ear skin tissue. Treatment with resin ethanol solution (Figure 6E) also reduced ear thickness and cell infiltration but to a lesser extent compared to the resin cream.

\section{Skin irritancy (toxicity) assessment}

The irritancy of the cream containing $5 \% \mathrm{w} / \mathrm{w}$ of D. polyandra resin and cream base was assessed in the MatTek Epiderm ${ }^{\mathrm{TM}}$ MTT viability assay. Both samples were classified as non-irritating according to irritancy scoring criteria, showing $\mathrm{ET}_{50}$ values of greater than $24.0 \mathrm{~h}$ compared to a $1.0 \%$ Triton X100 positive control with $\mathrm{ET}_{50}$ of $6.0 \mathrm{~h}$.

\section{DISCUSSION}

This study was undertaken as part of work to develop new anti-inflammatory drug therapies that may have application in the management of common skin inflammatory disorders such as dermatitis and psoriasis. Previously we had demonstrated that crude extracts of $D$. polyandra and clerodane diterpenoids PAA and PAB can inhibit markers of inflammation in acute and chronic murine models of TPA-induced skin inflammation $(6,8,10)$. In our previous work we had used ethanolic solutions of the plant extracts and compounds for application to the skin in the in vivo models. This present study was undertaken to examine the feasibility of formulating a leaf resin extract of $D$. polyandra into a topical formulation at concentration that could demonstrate in vivo activity as well as acceptable physical properties for further development as a prototype formulation for pre-clinical testing.

In this study we demonstrated that the leaf resin could be formulated in an oil-in-water cream formulation at a strength of $5 \% \mathrm{w} / \mathrm{w}$. At this concentration the cream formulation was able to significantly reduce ear oedema, inflammatory cell infiltration and production of the pro-inflammatory cytokine IL- $1 \beta$ in the ear tissue. 


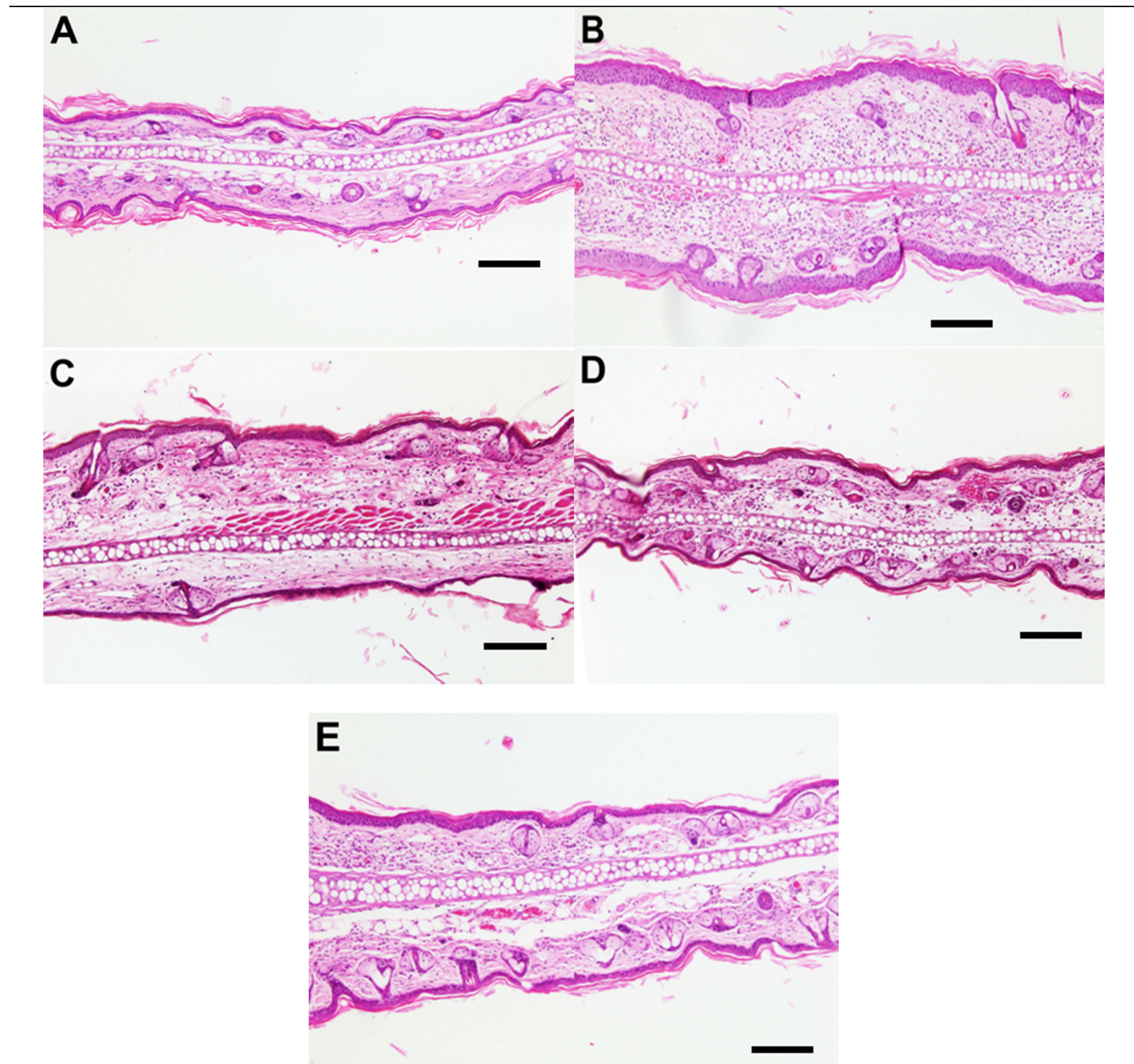

Figure 6. Histological analysis of the mouse ear tissue. Representative H\&E stained transversal cuts of mice ear sections, scale bar $100 \mu \mathrm{m}$. (A) No treatment - normal mouse ear; (B) TPA only treatment; (C) TPA with cream vehicle; (D) TPA with $5 \%$ resin cream; (E) TPA with resin $20 \mathrm{mg} / \mathrm{mL}$ in ethanol solution $(0.4 \mathrm{mg} / \mathrm{ear})$. TPA treatment induced an increase in ear thickness with epidermal hyperplasia and inflammatory cell infiltration (indicated by purple/black stained cells) (B). The 5\% resin cream (D) reduced ear thickness and the associated pathological features of inflammation to a greater extent than the cream base (C) or the resin dissolved in an ethanol vehicle (E).

The cream formulation was able to reduce these parameters of inflammation to a greater extent than a previously established dose of $0.4 \mathrm{mg} / \mathrm{ear}$ of the resin when delivered as an ethanol solution. This suggested that the cream formulation could deliver the active components of the extract to the site of action in the skin.

Increased ear thickening is often the first sign of skin irritation and local inflammation. This parameter is an indicator of number of processes that occur during skin inflammation, including increased vascular permeability, edema and proliferation of epidermal keratinocytes $(7,17,18)$.
Epidermal keratinocytes release high amounts of the pro-inflammatory cytokines TNF- $\alpha$ and IL- $1 \beta$, which consequently initiate a series of cellular inflammatory responses and further exacerbation of the symptoms $(19,20)$. Utilizing a combination of moisturizing cream and anti-inflammatory agents could offer optimization in treating irritant and allergic contact dermatitis (21).

We also conducted an in vitro release test using a Franz diffusion cell with a synthetic PVDF membrane to examine the release of the diterpenoids PAA and PAB from the formulation. 
In order for the intended therapeutic effects of topical preparations to be achieved, actives must first be liberated from the preparation to reach the surface of skin. The PVDF membrane is known to give reproducible results and has been recommended by the United States Food and Drug Administration (FDA) as a measure of batch consistency $(22,23)$. The resin cream allowed the release of both diterpenoid compounds in a reproducible manner, however the amounts released were low, with approximately $4 \%$ of PAA and $2 \%$ of PAB released after 8 hours. The amount of drug released from a semisolid preparation can be influenced by many factors including, drug physico-chemical properties, vehicle compositions and the interactions between them (24). Further studies using full-thickness human skin membranes instead of synthetic membranes (25) and over a more extended time period (up to 12 hours) are now needed to better predict in vivo release.

As the first stage in evaluating the safety and tolerability of the resin cream formulation and cream base these were assessed using a MatTek EpidermTM MTT viability assay. This is a threedimensional reconstructed human epidermis (RhE), constructed from human-derived nontransformed keratinocytes which can be used to assess dermal irritancy and toxicology $(26,27)$. This method is an Organization for Economic Cooperation and Development (OECD) Guideline approved method for assessing skin irritancy as an in vitro alternative to methods such as the Draize test in animals (28). Cell viability is determined after exposure of the RhE to the test substance and measured using an MTT viability assay. Irritant chemicals are identified by their ability to decrease cell viability below defined levels (28). In the present study the resin cream and cream base showed no reduction in cell viability after 24 hour of exposure and were classified as non-irritant. Further studies of chronic and repeated exposure, including in vivo models, are now required to further assess the tolerability and safety of the formulation.

According to USP regulations (29) on semisolid formulations, the product quality attributes should include but are not limited to the following: description, assay, uniformity, physicochemical properties and apparent viscosity. In addition, the appearance, tactile feeling, spreadability, and odour of formulations are crucial properties which closely relate to patient compliance (29). In this study, an oil-in-water cream formulation based on two emulsifiers, Span 40 and Polychol 15, was found to give the optimal spreadability, acceptable appearance, tactile feel, texture and odour.

The cream emulsion was also assessed using a centrifugal accelerated deterioration test. This centrifuge test is widely used as means to assess the long-term stability of a cream. In terms of a typical oil-in-water $(\mathrm{O} / \mathrm{W})$ cream, the oil phase has a tendency to separate and rise to the top of the system, leading to emulsion break up which is represented by phase separation (30). For the resin cream formulation used in this study the composition was finely tailored based on the hydrophile-lipophile balance (HLB) system (31). The blending of two emulsifiers, Span 40 with a HLB value of 6.7 and Polychol 15 with a HLB value of 13.0 gave rise to a HLB value of 11.5, which theoretically supported the soundness of this $\mathrm{O} / \mathrm{W}$ cream (31).

In the present study, formulations were freshly prepared for pharmacological and pharmaceutical assessments. Further studies are now required to measure the stability of the active components in the cream formulation, and to examine the influence of factors including temperature, $\mathrm{pH}$ and light. The use of standardized plant extracts for medical and complementary treatments has been increasingly popular. Given their complex chemical profiles, the contents of bioactive components had been recognized as a crucial criterion for natural products identification and quality control. In the case of plant $D$. polyandra, the two benzoyl ester clerodane diterpenoids PAA and $\mathrm{PAB}$ have been identified as most effective anti-inflammatory compounds (8). Further development of this formulation will require standardization of these compounds in different batches of plant extract.

\section{CONCLUSION}

Our early development study has demonstrated that the leaf resin from $D$. polyandra can be readily formulated into a cream-type dosage form. The physical characteristics of the prototype cream met criterion outlined in the United States Pharmacopoeia. Our formulation demonstrated efficacy in an acute mouse ear oedema model over a $6 \mathrm{~h}$ period. This was commensurate with a decrease in the pro-inflammatory cytokine IL-1 $\beta$. Importantly the prototype formulation lacked skin irritancy as assessed in an acute in vitro model. Overall, this study provides sound evidence that our prototype topical formulation product possesses favourable characteristics amenable to further development towards commercial application. 


\section{ACKNOWLEDGMENTS}

The authors thank the Chuulangun Aboriginal Corporation for their ongoing commitment to the collaborative research projects. We would also like to acknowledge Dr Lisa F. Pratt of MB Research Laboratories for overseeing the toxicity assessment of our prototype formulation containing $D$. polyandra resin using the MatTek EpiDerm ${ }^{\mathrm{TM}}$ MTT Viability Assay. This work was funded by a Development Grant from the National Health and Medical Research Council (NHMRC) (APP1017556).

\section{CONFLICT OF INTEREST}

The authors declare that there are no conflicts of interest regarding the content of this article.

\section{REFERENCES}

1. Enamandram M, Kimball AB. Psoriasis epidemiology: The interplay of genes and the environment. J Invest Dermatol, 2013; 133:287289.

2. GlobalData. Atopic Dermatitis - Drug Pipeline Analysis and Market Forecasts to 2016. 2010.

3. Melnikova I. Psoriasis market. Nat Rev Drug Discov, 2009; 8:767-768.

4. Armstrong AW, Robertson AD, Wu J, Schupp C, Lebwohl MG. Undertreatment, treatment trends, and treatment dissatisfaction among patients with psoriasis and psoriatic arthritis in the United States: Findings from the national psoriasis foundation surveys, 2003-2011. JAMA Dermatol, 2013; 149:1180-1185.

5. West J. Sapindaceae. Flora of Australia. Australian Government Publishing, Canberra, pp 4-163, 1985.

6. Simpson B, Claudie D, Smith N, Wang J, McKinnon R, Semple S. Evaluation of the antiinflammatory properties of Dodonaea polyandra, a Kaanju traditional medicine. J Ethnopharmacol, 2010; 132:340-343.

7. Rao T, Currie J, Shaffer A, Isakson P. Comparative evaluation of arachidonic acid (AA)- and tetradecanoylphorbol acetate (TPA)-induced dermal inflammation. Inflammation, 1993; 17:723741.

8. Simpson BS, Claudie DJ, Gerber JP, Pyke SM, Wang J, McKinnon RA, et al. In vivo activity of benzoyl ester clerodane diterpenoid derivatives from Dodonaea polyandra. J Nat Prod, 2011; 74:650-657.

9. Simpson BS, Claudie DJ, Smith NM, McKinnon RA, Semple SJ. Rare, seven-membered cyclic ether labdane diterpenoid from Dodonaea polyandra. Phytochemistry, 2012; 84:141-146.

10. Simpson BS, Luo X, Costabile M, Caughey GE, Wang J, Claudie DJ, et al. Polyandric acid A, a clerodane diterpenoid from the Australian medicinal plant Dodonaea polyandra, attenuates pro-inflammatory cytokine secretion in vitro and in vivo. J Nat Prod, 2014; 77:85-91.

11. Salinas-Sánchez DO, Herrera-Ruiz M, Pérez S, Jiménez-Ferrer E, Zamilpa A. Anti-inflammatory activity of hautriwaic acid isolated from Dodonaea viscosa leaves. Molecules, 2012; 17:4292-4299.

12. Salinas-Sánchez DO, Zamilpa A, Pérez S, HerreraRuiz M, Tortoriello J, González-Cortazar M, et al. Effect of hautriwaic acid isolated from Dodonaea viscosa in a model of kaolin/carrageenan-induced monoarthritis. Planta Med, 2015; DOI: 10.1055/s0035-1546197(online).

13. Simpson BS. PhD Thesis: Chemical and Pharmacological Evaluation of Dodonaea polyandra. University of South Australia, Adelaide, 2011.

14. Food and Drug Administration. CDER Data Standards Manual Definitions for Topical Dosage Forms.

http:/www.fda.gov/ohrms/dockets/ac/06/briefing/ 2006-4241B1-02-30-FDA-

Topical $\% 20$ Dosage $\% 20$ Forms $\% 20$ Definitions $\% 2$ 0Old\%20\%20.pdf, 2006.

15. Anchisi C, Maccioni AM, Sinico C, Valenti D. Stability studies of new cosmetic formulations with vegetable extracts as functional agents. Il Farmaco, 2001; 56:427-431.

16. Pratt LF. MatTek EpiDermTM MTT Viability Assay Project Number 13-21604.19. Unpublished Report by MB Research Laboratories. MB Research Laboratories, Spinnerstown, PA, 2013.

17. Carlson R, Lynn ON-D, Chang J, Lewis A. Modulation of mouse ear edema by cyclooxygenase and lipoxygenase inhibitors and other pharmacologic agents. Agents Actions, 1985; 17:197-204.

18. Inoue $\mathrm{H}$, Mori $\mathrm{T}$, Shibata $\mathrm{S}$, Koshihara $\mathrm{Y}$. Modulation by glycyrrhetinic acid derivatives of TPA-induced mouse ear oedema. Br J Pharmacol, 1989; 96:204-210.

19. Novak N, Bieber T, Leung DYM. Immune mechanisms leading to atopic dermatitis. J Allergy Clin Immunol, 2003; 112:S128-S139.

20. Proksch E, Fölster-Holst R, Jensen J-M. Skin barrier function, epidermal proliferation and differentiation in eczema. J Dermatol Sci, 2006; 43:159-169.

21. zur Mühlen A, Klotz A, Weimans S, Veeger M, Thörner B, Diener B, et al. Using skin models to assess the effects of a protection cream on skin barrier function. Skin Pharmacol Physiol, 2004; 17:167-175.

22. Fan Q, Sirkar KK, Wang Y, Michniak B. In vitro delivery of doxycycline hydrochloride based on a porous membrane-based aqueous-organic partitioning system. J Control Release 2004; 98:355-65.

23. Shah VP, Elkins J, Lam S-Y, Skelly JP. Determination of in vitro drug release from hydrocortisone creams. Int J Pharm. 1989; 53:53-9. 
24. Eros I, Abu-Eida EY, Csóka I, Sánta Z, Cserne A, Kövér T. Optimization of drug release from dermatological semisolid preparations. Drug Dev Res. 2003; 59:316-25.

25. OECD. OECD Guideline for the Testing of Chemicals 428. Skin Absorption: in vitro Method. 2004.

26. Faller C, Bracher M, Dami N, Roguet R. Predictive ability of reconstructed human epidermis equivalents for the assessment of skin irritation of cosmetics. Toxicol In Vitro, 2002; 16:557-572.

27. MatTek Corporation. Data Sheet. EpiDerm ${ }^{\mathrm{TM}}$ Tissue Model.

28. http://www.mattek.com/EpiDerm/data-sheet. MatTek, Ashland, 2015.
29. OECD. OECD Test Guideline No 431. In vitro skin corrosion: human skin model test. OECD Guidelines for the Testing of Chemicals, Section 4 Health Effects 2004.

30. Margareth RCM. Topical and Transdermal Drug Products - Product Quality Tests. United States Pharmacopeia and National Formulary (USP 30NF 35). Pharmacopeial Convention, Rockville, MD, USA, 2012.

31. McClements DJ. Critical review of techniques and methodologies for characterization of emulsion stability. Crit Rev Food Sci Nutr, 2007; 47:611649.

32. ICI Americas Inc. The HLB System - a time saving guide to emulsifier selection. Wilmington, Delaware, 1980. 


\section{Criteria used for the determination of physical properties of trial formulations}

a) Spreadability of formulations was determined according to the criteria outlined in table S1. Vehicles rating at " 0 " or " 1 " were considered acceptable.

b) Acceptability was determined with subjective assessment of appearance, tactile feel, texture and odour.

c) Gravitational stability was assessed as $X$ (not stable, phase separation occurs) or $\sqrt{ }$ (stable, no phase separation). Gravitational stability assessment was not applied to gels.

Table S1. Criteria used to assess spreadability of formulations

\begin{tabular}{cl}
\hline Score & Description \\
\hline-2 & Formulation or vehicle appears as a solid state, which cannot be spread around the application site. \\
-1 & Formulation or vehicle has to be applied with force greater than normal to achieve a desirable spread. \\
0 & Formulation or vehicle displays good spreadability with desirable stay-on semisolid property. \\
1 & $\begin{array}{l}\text { Formulation or vehicle displays good spreadability with a slight tendency to flow over the skin } \\
\text { surface. }\end{array}$ \\
& Formulation or vehicle has low viscosity with high tendency to flow over the skin surface.
\end{tabular}

\section{Formulation ingredients and physical properties of trial formulations}

The ingredients and physical properties of different series of trial formulations are summarised in Tables S2 to S15. The preservative used in formulations was an ethanolic solution of methyl paraben and propyl paraben.

Table S2. Formulation ingredients and physical properties of trial formulations (series 1-1, Cream formulations)

\begin{tabular}{|c|c|c|c|c|}
\hline $\begin{array}{l}\text { Series 1-1 } \\
\text { Cream }\end{array}$ & & & & \\
\hline & Formulation & lumber & & \\
\hline Ingredients & 1 & 2 & 3 & 4 \\
\hline Glycerol monostearate & $1.2 \mathrm{~g}$ & $0.72 \mathrm{~g}$ & $1.2 \mathrm{~g}$ & $1.2 \mathrm{~g}$ \\
\hline Liquid paraffin & $0.5 \mathrm{~g}$ & $0.3 \mathrm{~g}$ & $0.5 \mathrm{~g}$ & $0.5 \mathrm{~g}$ \\
\hline Stearic acid & $0.5 \mathrm{~g}$ & $0.3 \mathrm{~g}$ & $0.5 \mathrm{~g}$ & $0.5 \mathrm{~g}$ \\
\hline Lauryl sulfate & $0.03 \mathrm{~g}$ & $0.03 \mathrm{~g}$ & $0.03 \mathrm{~g}$ & $0.03 \mathrm{~g}$ \\
\hline Glycerol & $0.5 \mathrm{~g}$ & $0.5 \mathrm{~g}$ & $0.5 \mathrm{~g}$ & $0.5 \mathrm{~g}$ \\
\hline Preservative & $0.125 \mathrm{~mL}$ & $0.1 \mathrm{~mL}$ & $0.15 \mathrm{~mL}$ & $0.1 \mathrm{~mL}$ \\
\hline Absolute ethanol & - & - & - & $0.6 \mathrm{~g}$ \\
\hline Purified water & QS to $12.5 \mathrm{~g}$ & QS to $10 \mathrm{~g}$ & QS to $15 \mathrm{~g}$ & QS to $10 \mathrm{~g}$ \\
\hline In vitro physical prop & & & & \\
\hline Spreadability & 0 & -1 & 0 & 1 \\
\hline Acceptability & $\sqrt{ }$ & $\sqrt{ }$ & $\sqrt{ }$ & $\sqrt{ }$ \\
\hline Gravitational stability & $x$ & $x$ & $x$ & $\times$ \\
\hline
\end{tabular}


Table S3. Formulation ingredients and physical properties of trial formulations (series 1-2, Cream formulations)

\begin{tabular}{|c|c|c|c|c|c|c|c|c|}
\hline \multicolumn{9}{|l|}{$\begin{array}{l}\text { Series 1-2 } \\
\text { Cream }\end{array}$} \\
\hline & \multicolumn{8}{|c|}{ Formulation number } \\
\hline Ingredients & 1 & 2 & 3 & 4 & 5 & 6 & 7 & 8 \\
\hline Stearyl alcohol & $1 \mathrm{~g}$ & $1 \mathrm{~g}$ & $0.8 \mathrm{~g}$ & $1 \mathrm{~g}$ & $1 \mathrm{~g}$ & $1 \mathrm{~g}$ & $1 \mathrm{~g}$ & $1 \mathrm{~g}$ \\
\hline Vaseline & $2.5 \mathrm{~g}$ & $1.25 \mathrm{~g}$ & $\lg$ & $1.125 \mathrm{~g}$ & $1.125 \mathrm{~g}$ & $1.125 \mathrm{~g}$ & $1.125 \mathrm{~g}$ & $1.125 \mathrm{~g}$ \\
\hline Tween 80 & $0.35 \mathrm{~g}$ & $0.35 \mathrm{~g}$ & $0.35 \mathrm{~g}$ & $0.35 \mathrm{~g}$ & $0.2 \mathrm{~g}$ & $0.225 \mathrm{~g}$ & $0.15 \mathrm{~g}$ & $0.375 \mathrm{~g}$ \\
\hline Span 80 & $0.35 \mathrm{~g}$ & $0.35 \mathrm{~g}$ & $0.35 \mathrm{~g}$ & $0.35 \mathrm{~g}$ & $0.2 \mathrm{~g}$ & $0.075 \mathrm{~g}$ & $0.05 \mathrm{~g}$ & $0.125 \mathrm{~g}$ \\
\hline Glycerol & $1 \mathrm{~g}$ & $1 \mathrm{~g}$ & $1 \mathrm{~g}$ & $1 \mathrm{~g}$ & $1 \mathrm{~g}$ & $\lg$ & $1 \mathrm{~g}$ & $0.8 \mathrm{~g}$ \\
\hline Propylene glycol & l & / & / & / & $0.3 \mathrm{~g}$ & $0.275 \mathrm{~g}$ & $0.375 \mathrm{~g}$ & $0.275 \mathrm{~g}$ \\
\hline Preservative & $0.1 \mathrm{~mL}$ & $0.1 \mathrm{~mL}$ & $0.1 \mathrm{~mL}$ & $0.1 \mathrm{~mL}$ & $0.1 \mathrm{~mL}$ & $0.1 \mathrm{~mL}$ & $0.1 \mathrm{~mL}$ & $0.1 \mathrm{~mL}$ \\
\hline Purified water & $\begin{array}{l}\text { QS to } \\
10 \mathrm{~g}\end{array}$ & $\begin{array}{l}\text { QS to } \\
10 \mathrm{~g}\end{array}$ & $\begin{array}{l}\text { QS to } \\
10 \mathrm{~g}\end{array}$ & $\begin{array}{l}\text { QS to } \\
10 \mathrm{~g}\end{array}$ & $\begin{array}{l}\text { QS to } \\
10 \mathrm{~g}\end{array}$ & $\begin{array}{l}\text { QS to } \\
10 \mathrm{~g}\end{array}$ & $\begin{array}{l}\text { QS to } \\
10 \mathrm{~g}\end{array}$ & QS to $10 \mathrm{~g}$ \\
\hline \multicolumn{9}{|c|}{ In vitro physical properties } \\
\hline Spreadability & -2 & -1 & 2 & 1 & 1 & 1 & 1 & 1 \\
\hline Acceptability & $x$ & $x$ & $x$ & $\sqrt{ }$ & $\sqrt{ }$ & $\sqrt{ }$ & $\sqrt{ }$ & $\sqrt{ }$ \\
\hline $\begin{array}{l}\text { Gravitational } \\
\text { stability }\end{array}$ & $\times$ & $\times$ & $x$ & $\times$ & $x$ & $x$ & $x$ & $x$ \\
\hline
\end{tabular}

Table S4. Formulation ingredients and physical properties of trial formulations (series 1-3, based on Carbopol Hydrogel)

Series 1-3

Carbopol Hydrogel

\begin{tabular}{|c|c|c|c|c|c|c|c|c|c|}
\hline \multirow[b]{2}{*}{ Ingredients } & \multicolumn{9}{|c|}{ Formulation number } \\
\hline & 1 & 2 & 3 & 4 & 5 & 6 & 7 & 8 & 9 \\
\hline Carbopol 934P & $0.05 \mathrm{~g}$ & $0.25 \mathrm{~g}$ & $0.3 \mathrm{~g}$ & $0.35 \mathrm{~g}$ & $0.4 \mathrm{~g}$ & $0.3 \mathrm{~g}$ & $0.25 \mathrm{~g}$ & $0.2 \mathrm{~g}$ & $0.12 \mathrm{~g}$ \\
\hline Glycerol & $0.2 \mathrm{~g}$ & $0.2 \mathrm{~g}$ & $0.2 \mathrm{~g}$ & $0.4 \mathrm{~g}$ & $0.2 \mathrm{~g}$ & $0.2 \mathrm{~g}$ & $0.25 \mathrm{~g}$ & $0.3 \mathrm{~g}$ & $0.2 \mathrm{~g}$ \\
\hline Propylene glycol & - & - & - & - & - & $4 g$ & $4 g$ & $4 g$ & $3.6 \mathrm{~g}$ \\
\hline Preservative & $0.1 \mathrm{~mL}$ & $0.1 \mathrm{~mL}$ & $0.1 \mathrm{~mL}$ & $0.1 \mathrm{~mL}$ & $0.1 \mathrm{~mL}$ & $0.1 \mathrm{~mL}$ & $0.1 \mathrm{~mL}$ & $0.1 \mathrm{~mL}$ & $0.1 \mathrm{~mL}$ \\
\hline Absolute ethanol & - & - & - & - & - & $2.0 \mathrm{~g}$ & $2.0 \mathrm{~g}$ & $2.0 \mathrm{~g}$ & $1.2 \mathrm{~g}$ \\
\hline $\mathrm{NaOH}$ & - & - & - & - & - & - & - & - & \\
\hline Purified water & $\begin{array}{l}\text { QS to } \\
10 \mathrm{~g}\end{array}$ & $\begin{array}{l}\text { QS to } \\
10 \mathrm{~g}\end{array}$ & $\begin{array}{l}\text { QS to } \\
10 \mathrm{~g}\end{array}$ & $\begin{array}{l}\text { QS to } \\
10 \mathrm{~g}\end{array}$ & $\begin{array}{l}\text { QS to } \\
10 \mathrm{~g}\end{array}$ & $\begin{array}{l}\text { QS to } \\
10 \mathrm{~g}\end{array}$ & $\begin{array}{l}\text { QS to } \\
10 \mathrm{~g}\end{array}$ & $\begin{array}{l}\text { QS to } \\
10 \mathrm{~g}\end{array}$ & $\begin{array}{l}\text { QS to } \\
10 \mathrm{~g}\end{array}$ \\
\hline \multicolumn{10}{|c|}{ In vitro physical properties } \\
\hline Spreadability & -2 & -1 & 1 & 0 & 0 & 1 & 0 & -1 & 1 \\
\hline Acceptability & $\sqrt{ }$ & $\sqrt{ }$ & $\sqrt{ }$ & $\sqrt{ }$ & $\sqrt{ }$ & $x$ & $x$ & $\times$ & $\times$ \\
\hline
\end{tabular}


Table S5. Formulation ingredients and physical properties of trial formulations (series 1-4, based on PEG Hydrogel) Series 1-4

PEG Hydrogel

\begin{tabular}{|c|c|c|c|c|c|c|c|}
\hline & Formul & n numb & & & & & \\
\hline Ingredients & 1 & 2 & 3 & 4 & 5 & 6 & 7 \\
\hline PEG 4000 & $4.5 \mathrm{~g}$ & $3.5 \mathrm{~g}$ & $3 g$ & $3.5 \mathrm{~g}$ & $3 g$ & $3.5 \mathrm{~g}$ & $6.5 \mathrm{~g}$ \\
\hline PEG 300 & $4.5 \mathrm{~g}$ & $3.5 \mathrm{~g}$ & $3 g$ & $3 g$ & $3 g$ & $3 g$ & / \\
\hline Glycerol & $0.6 \mathrm{~g}$ & $1 \mathrm{~g}$ & $1.2 \mathrm{~g}$ & $1 \mathrm{~g}$ & $1.5 \mathrm{~g}$ & $1.25 \mathrm{~g}$ & $1.2 \mathrm{~g}$ \\
\hline Preservative & $0.1 \mathrm{~mL}$ & $0.1 \mathrm{~mL}$ & $0.1 \mathrm{~mL}$ & $0.1 \mathrm{~mL}$ & $0.1 \mathrm{~mL}$ & $0.1 \mathrm{~mL}$ & $0.1 \mathrm{~mL}$ \\
\hline Purified water & $\begin{array}{l}\text { QS to } \\
10 \mathrm{~g}\end{array}$ & $\begin{array}{l}\text { QS to } \\
10 \mathrm{~g}\end{array}$ & $\begin{array}{l}\text { QS to } \\
10 \mathrm{~g}\end{array}$ & $\begin{array}{l}\text { QS to } \\
10 \mathrm{~g}\end{array}$ & $\begin{array}{l}\text { QS to } \\
10 \mathrm{~g}\end{array}$ & $\begin{array}{l}\text { QS to } \\
10 \mathrm{~g}\end{array}$ & QS to $10 \mathrm{~g}$ \\
\hline In vitro physic & erties & & & & & & \\
\hline Spreadability & -3 & -1 & 1 & 1 & 0 & 1 & 1 \\
\hline Acceptability & $\times$ & $x$ & $x$ & $x$ & $\sqrt{ }$ & $\sqrt{ }$ & $x$ \\
\hline
\end{tabular}

Table S6. Formulation ingredients and physical properties of trial formulations (series 1-5, based on Pluronic F-127 Gel)

Series 1-5

Pluronic F-127 Gel

\begin{tabular}{llll}
\hline \multicolumn{4}{l}{ Formulation number } \\
\hline Ingredients & 1 & 2 & 3 \\
Pluronic F-127 & $2.3 \mathrm{~g}$ & $3 \mathrm{~g}$ & $3 \mathrm{~g}$ \\
Propylene glycol & $0.1 \mathrm{~g}$ & $0.2 \mathrm{~g}$ & $0.2 \mathrm{~g}$ \\
Polyvinylpyrrolidone K90 & - & - & $0.5 \mathrm{~g}$ \\
Preservative & $0.1 \mathrm{~mL}$ & $0.1 \mathrm{~mL}$ & $0.1 \mathrm{~mL}$ \\
Absolute ethanol & $1.8 \mathrm{~g}$ & $1.2 \mathrm{~g}$ & $1.2 \mathrm{~g}$ \\
Purified water & $\mathrm{QS}$ to $10 \mathrm{~g}$ & $\mathrm{QS}$ to $10 \mathrm{~g}$ & $\mathrm{QS}$ to $10 \mathrm{~g}$ \\
In vitro physical properties & & & \\
Spreadability & 2 & 2 & 2 \\
Acceptability & $\sqrt{ }$ & $\times$ \\
\hline QS= quantum sufficiat (sufficient quantity) & & \\
\hline
\end{tabular}


Table S7. Formulation ingredients and physical properties of trial formulations (series 2-1).

\begin{tabular}{|c|c|c|c|c|c|c|c|c|}
\hline \multicolumn{9}{|l|}{ Series 2-1 } \\
\hline \multirow[b]{2}{*}{ Ingredients } & \multicolumn{8}{|c|}{ Formulation number } \\
\hline & 1 & 2 & 3 & 4 & 5 & 6 & 7 & 8 \\
\hline Stearyl alcohol & $1 \mathrm{~g}$ & $1 \mathrm{~g}$ & $1 \mathrm{~g}$ & - & - & - & - & - \\
\hline Vaseline & $1.2 \mathrm{~g}$ & $1.2 \mathrm{~g}$ & $1.2 \mathrm{~g}$ & $1.2 \mathrm{~g}$ & $1.2 \mathrm{~g}$ & $0.6 \mathrm{~g}$ & $0.6 \mathrm{~g}$ & $1.2 \mathrm{~g}$ \\
\hline Propylene glycol & $0.5 \mathrm{~g}$ & $0.3 \mathrm{~g}$ & $0.2 \mathrm{~g}$ & $0.2 \mathrm{~g}$ & $0.2 \mathrm{~g}$ & $0.2 \mathrm{~g}$ & $0.2 \mathrm{~g}$ & $0.2 \mathrm{~g}$ \\
\hline Captex 300 EP/NF & - & - & - & $1 \mathrm{~g}$ & - & $1 \mathrm{~g}$ & $1 \mathrm{~g}$ & - \\
\hline Isopropyl myristate & - & - & - & - & $1 \mathrm{~g}$ & - & - & $0.5 \mathrm{~g}$ \\
\hline Glycerol & - & - & - & - & - & - & $0.6 \mathrm{~g}$ & $0.5 \mathrm{~g}$ \\
\hline Paraffin oil & - & - & - & - & - & $0.6 \mathrm{~g}$ & - & - \\
\hline Absolute ethanol & $1.2 \mathrm{~g}$ & $1.2 \mathrm{~g}$ & $1.2 \mathrm{~g}$ & $1.2 \mathrm{~g}$ & $1.2 \mathrm{~g}$ & $1.2 \mathrm{~g}$ & $1.2 \mathrm{~g}$ & $1.2 \mathrm{~g}$ \\
\hline Polawax & $0.5 \mathrm{~g}$ & $1 \mathrm{~g}$ & $1.5 \mathrm{~g}$ & $1.5 \mathrm{~g}$ & $1.5 \mathrm{~g}$ & $1.5 \mathrm{~g}$ & $1.5 \mathrm{~g}$ & $1.5 \mathrm{~g}$ \\
\hline Preservative & $0.1 \mathrm{~mL}$ & $0.1 \mathrm{~mL}$ & $0.1 \mathrm{~mL}$ & $0.1 \mathrm{~mL}$ & $0.1 \mathrm{~mL}$ & $0.1 \mathrm{~mL}$ & $0.1 \mathrm{~mL}$ & $0.1 \mathrm{~mL}$ \\
\hline Purified water & $\begin{array}{l}\text { QS to } \\
9.5 \mathrm{~g}\end{array}$ & $\begin{array}{l}\text { QS to } \\
9.5 \mathrm{~g}\end{array}$ & $\begin{array}{l}\text { QS to } \\
9.5 \mathrm{~g}\end{array}$ & $\begin{array}{l}\text { QS to } \\
9.5 \mathrm{~g}\end{array}$ & $\begin{array}{l}\text { QS to } \\
9.5 \mathrm{~g}\end{array}$ & QS to $9.5 \mathrm{~g}$ & $\begin{array}{l}\text { QS to } \\
9.5 \mathrm{~g}\end{array}$ & $\begin{array}{l}\text { QS to } \\
9.5 \mathrm{~g}\end{array}$ \\
\hline \multicolumn{9}{|c|}{ In vitro physical properties } \\
\hline Spreadability & 2 & 2 & 2 & 1 & 1 & \multirow{3}{*}{$\begin{array}{l}\text { failed to } \\
\text { form } \\
\text { emulsion }\end{array}$} & 1 & 1 \\
\hline Acceptability & $x$ & $x$ & $x$ & $x$ & $x$ & & $\sqrt{ }$ & $\sqrt{ }$ \\
\hline $\begin{array}{l}\text { Gravitational } \\
\text { stability }\end{array}$ & $x$ & $x$ & $x$ & $\sqrt{ }$ & $\sqrt{ }$ & & $\sqrt{ }$ & $x$ \\
\hline
\end{tabular}

Table S10. Formulation ingredients and physical properties of trial formulations (series 3-1), based on cream base used for fluticasone propionate cream.

\begin{tabular}{|c|c|c|}
\hline $\begin{array}{l}\text { Series 3-1 } \\
\text { Based on fluticasone pr }\end{array}$ & (FP) cream & \\
\hline & Formulatio & \\
\hline Ingredients & FP-1 & FP-2 \\
\hline Cetostearyl alcohol & $0.7 \mathrm{~g}$ & $0.7 \mathrm{~g}$ \\
\hline Isopropyl myristate & $0.5 \mathrm{~g}$ & - \\
\hline Ceteareth-20 & $0.4 \mathrm{~g}$ & - \\
\hline Liquid paraffin & $1 \mathrm{~g}$ & - \\
\hline Propylene glycol & $0.4 \mathrm{~g}$ & - \\
\hline Dimethicone & - & $0.5 \mathrm{~g}$ \\
\hline Span 80 & - & $0.4 \mathrm{~g}$ \\
\hline Polychol 40 & - & $1 \mathrm{~g}$ \\
\hline Absolute ethanol & $1.2 \mathrm{~g}$ & $1.2 \mathrm{~g}$ \\
\hline Preservative & $0.1 \mathrm{~mL}$ & $0.1 \mathrm{~mL}$ \\
\hline Purified water & QS to $9.5 \mathrm{~g}$ & QS to $9.5 \mathrm{~g}$ \\
\hline In vitro physical prop & & \\
\hline Spreadability & 2 & 1 \\
\hline Acceptability & $\sqrt{ }$ & $\sqrt{ }$ \\
\hline Gravitational stability & $x$ & $x$ \\
\hline
\end{tabular}


Table S11. Formulation ingredients and physical properties of trial formulations (series 3-2), based on cream base used for alum cream.

\section{Series 3-2}

Based on Alum Cream formulation

\begin{tabular}{ll}
\hline & Formulation number \\
\hline Ingredients & Alum-1 \\
Cetostearyl alcohol & $0.4 \mathrm{~g}$ \\
Octyldodecanol & $0.5 \mathrm{~g}$ \\
Lanolin alcohol & $0.4 \mathrm{~g}$ \\
Cremophor EL & $0.2 \mathrm{~g}$ \\
Vaseline & $0.2 \mathrm{~g}$ \\
Absolute ethanol & $1.2 \mathrm{~g}$ \\
Preservative & $0.1 \mathrm{~mL}$ \\
Purified water & QS to 9.5g \\
In vitro physical properties & \\
Spreadability & 2 \\
Acceptability & $\times$ \\
Gravitational stability & $\times$ \\
\hline QS= quantum sufficiat (sufficient quantity) \\
\hline
\end{tabular}

Table S12. Formulation ingredients and physical properties of trial formulations (series 3-3), based on the base of an antiseptic cream formulation

Series 3-3

Antiseptic Cream base

\begin{tabular}{llll}
\hline & Formulation number & & \\
\hline Ingredients & AtS-1 & AtS-2 & AtS-3 \\
Polawax & $0.5 \mathrm{~g}$ & $0.8 \mathrm{~g}$ & $0.8 \mathrm{~g}$ \\
Lanolin & $0.1 \mathrm{~g}$ & $0.5 \mathrm{~g}$ & $0.5 \mathrm{~g}$ \\
Cetearyl alcohol & $0.7 \mathrm{~g}$ & $0.3 \mathrm{~g}$ & $0.3 \mathrm{~g}$ \\
Dimethicone & $0.3 \mathrm{~g}$ & $0.3 \mathrm{~g}$ & $0.3 \mathrm{~g}$ \\
Liquid paraffin & $1.5 \mathrm{~g}$ & - & $1 \mathrm{~g}$ \\
Isoeicosane & - & $1.2 \mathrm{~g}$ & - \\
Propylene glycol & - & - & $0.4 \mathrm{~g}$ \\
Absolute ethanol & $1.2 \mathrm{~g}$ & $1.2 \mathrm{~g}$ & $1.2 \mathrm{~g}$ \\
Preservative & $0.1 \mathrm{~mL}$ & $0.1 \mathrm{~mL}$ & $0.1 \mathrm{~mL}$ \\
Purified water & $\mathrm{QS}$ to $9.5 \mathrm{~g}$ & $\mathrm{QS}$ to $9.5 \mathrm{~g}$ & $\mathrm{QS}$ to $9.5 \mathrm{~g}$ \\
In vitro physical properties & & & \\
Spreadability & 1 & 1 & 1 \\
Acceptability & $\times$ & $\sqrt{ }$ & $\sqrt{ }$ \\
Gravitational stability & $\sqrt{ }$ & $\times$ & $\sqrt{ }$ \\
\hline QS= quantum sufficiat (sufficient quantity) & & \\
\hline
\end{tabular}


Table S13. Formulation ingredients and physical properties of trial formulations (series 3-4), based on the base of a baby cream formulation

Series 3-4

Baby Cream base

\begin{tabular}{lll}
\hline & Formulation number & \\
\hline Ingredients & $\mathrm{BbC}-1$ & $\mathrm{BbC}-2$ \\
Silica & $0.8 \mathrm{~g}$ & $0.2 \mathrm{~g}$ \\
Polawax & $1 \mathrm{~g}$ & - \\
Cetayl alcohol & $0.3 \mathrm{~g}$ & $0.6 \mathrm{~g}$ \\
Lanolin & $0.2 \mathrm{~g}$ & $0.3 \mathrm{~g}$ \\
Glycerol & $0.5 \mathrm{~g}$ & $1 \mathrm{~g}$ \\
Ceteareth-20 & - & $0.4 \mathrm{~g}$ \\
Span 80 & - & $0.3 \mathrm{~g}$ \\
Absolute ethanol & $1.2 \mathrm{~g}$ & $1.2 \mathrm{~g}$ \\
Preservative & $0.1 \mathrm{~mL}$ & $0.1 \mathrm{~mL}$ \\
Purified water & $\mathrm{QS}$ to $9.5 \mathrm{~g}$ & $\mathrm{QS} \mathrm{to} 9.5 \mathrm{~g}$ \\
In vitro physical properties & & \\
Spreadability & 2 & 1 \\
Acceptability & $\times$ & $\sqrt{ }$ \\
Gravitational stability & $\times$ & \\
\hline QS= quantum sufficiat (sufficient quantity) &
\end{tabular}

Table S14. Formulation ingredients and physical properties of trial formulations (series 3-5), based on the base of a betamethasone valerate ointment formulation

Series 3-5

Based on betamethasone valerate ointment base

\begin{tabular}{llll}
\hline & Formulation number & & \\
\hline Ingredients & BVO-1 & BVO-2 & BVO-3 \\
Vaseline & $5.8 \mathrm{~g}$ & $5.8 \mathrm{~g}$ & $7 \mathrm{~g}$ \\
Liquid paraffin & $1.5 \mathrm{~g}$ & $1.5 \mathrm{~g}$ & $1.5 \mathrm{~g}$ \\
Cetostearyl alcohol & $0.1 \mathrm{~g}$ & $0.1 \mathrm{~g}$ & $0.6 \mathrm{~g}$ \\
Ceteareth-20 & $0.1 \mathrm{~g}$ & $0.1 \mathrm{~g}$ & $0.4 \mathrm{~g}$ \\
Polychol 40 & - & $0.5 \mathrm{~g}$ & - \\
Absolute ethanol & $2 \mathrm{~g}$ & $1.5 \mathrm{~g}$ & - \\
Preservative & $0.1 \mathrm{~mL}$ & $0.1 \mathrm{~mL}$ & $0.1 \mathrm{~mL}$ \\
In vitro physical properties & & & \\
Spreadability & 0 & 0 & 0 \\
Acceptability & $\sqrt{ }$ & $\times$ & $\times$ \\
Gravitational stability & $\times$ & $\times$ & $\times$ \\
\hline QS= quantum sufficiat (sufficient quantity) & & \\
\hline
\end{tabular}


Table S15. Formulation ingredients and physical properties of trial formulations (series 3-6), based on a coal tar and allantoin cream formulation base.

Series 3-6

Coal tar and allantoin cream base

\begin{tabular}{|c|c|c|c|c|}
\hline \multirow[b]{2}{*}{ Ingredients } & \multicolumn{4}{|c|}{ Formulation number } \\
\hline & CTA-1 & CTA-2a & CTA-2b & CTA-2c \\
\hline Stearic acid & $1.5 \mathrm{~g}$ & $1.2 \mathrm{~g}$ & $1.2 \mathrm{~g}$ & $1.2 \mathrm{~g}$ \\
\hline Lanolin & $0.2 \mathrm{~g}$ & $0.2 \mathrm{~g}$ & $0.2 \mathrm{~g}$ & $0.2 \mathrm{~g}$ \\
\hline Triethanolamine & $0.4 \mathrm{~g}$ & $0.4 \mathrm{~g}$ & $0.4 \mathrm{~g}$ & $0.4 \mathrm{~g}$ \\
\hline Glycerol & $1.2 \mathrm{~g}$ & $1.2 \mathrm{~g}$ & $1.2 \mathrm{~g}$ & $1.2 \mathrm{~g}$ \\
\hline Captex 300 EP/NF & - & $0.3 \mathrm{~g}$ & - & - \\
\hline Octyldodecanol & - & - & $0.3 \mathrm{~g}$ & - \\
\hline Dimethicone & - & - & - & $0.3 \mathrm{~g}$ \\
\hline Absolute ethanol & $1.2 \mathrm{~g}$ & $1.2 \mathrm{~g}$ & $1.2 \mathrm{~g}$ & $1.2 \mathrm{~g}$ \\
\hline Preservative & $0.1 \mathrm{~mL}$ & $0.1 \mathrm{~mL}$ & $0.1 \mathrm{~mL}$ & $0.1 \mathrm{~mL}$ \\
\hline Purified water & QS to $9.5 \mathrm{~g}$ & QS to $9.5 \mathrm{~g}$ & QS to $9.5 \mathrm{~g}$ & QS to $9.5 \mathrm{~g}$ \\
\hline \multicolumn{5}{|c|}{ In vitro physical properties } \\
\hline Spreadability & -1 & 1 & Failed to form emulsion & 1 \\
\hline Acceptability & $\times$ & $\sqrt{ }$ & & $\sqrt{ }$ \\
\hline Gravitational stability & $\sqrt{ }$ & $\sqrt{ }$ & & $\sqrt{ }$ \\
\hline
\end{tabular}


J Pharm Pharm Sci (www.cspsCanada.org) 18(4) 578 - 599, 2015

Table S8. Formulation ingredients and physical properties of trial formulations (series 2-2).

Series 2-2

\begin{tabular}{|c|c|c|c|c|c|c|c|c|c|c|c|c|c|}
\hline & Formu & tion nur & ber & & & & & & & & & & \\
\hline Ingredients & 1 & 2 & 3 & 4 & 5 & 6 & 7 & 8 & 9 & 10 & 11 & 12 & 13 \\
\hline $\begin{array}{l}\text { Glycerol } \\
\text { monostearate }\end{array}$ & $1.2 \mathrm{~g}$ & $1.2 \mathrm{~g}$ & $1.2 \mathrm{~g}$ & $1.2 \mathrm{~g}$ & $1.2 \mathrm{~g}$ & $1.2 \mathrm{~g}$ & $1.2 \mathrm{~g}$ & $1.2 \mathrm{~g}$ & $1.2 \mathrm{~g}$ & $1.2 \mathrm{~g}$ & $0.8 \mathrm{~g}$ & $1.4 \mathrm{~g}$ & $1.2 \mathrm{~g}$ \\
\hline Polychol 40 & $1 \mathrm{~g}$ & $1 \mathrm{~g}$ & $1 \mathrm{~g}$ & $1 \mathrm{~g}$ & $1 \mathrm{~g}$ & $1 \mathrm{~g}$ & $1 \mathrm{~g}$ & $0.5 \mathrm{~g}$ & $0.2 \mathrm{~g}$ & - & $1 \mathrm{~g}$ & $0.8 \mathrm{~g}$ & $0.6 \mathrm{~g}$ \\
\hline Glycerol & $0.5 \mathrm{~g}$ & $0.5 \mathrm{~g}$ & $0.3 \mathrm{~g}$ & - & - & - & - & - & - & - & - & - & - \\
\hline Stearyl alcohol & - & $0.4 \mathrm{~g}$ & $0.2 \mathrm{~g}$ & $0.5 \mathrm{~g}$ & $0.5 \mathrm{~g}$ & $0.5 \mathrm{~g}$ & $0.5 \mathrm{~g}$ & $0.5 \mathrm{~g}$ & $0.5 \mathrm{~g}$ & $0.5 \mathrm{~g}$ & $0.3 \mathrm{~g}$ & - & - \\
\hline Polychol 15 & - & - & - & - & - & - & - & $0.5 \mathrm{~g}$ & $0.8 \mathrm{~g}$ & $1 \mathrm{~g}$ & - & - & - \\
\hline Dimethicone & - & - & - & - & - & - & - & - & - & - & $0.2 \mathrm{~g}$ & - & - \\
\hline Propylene glycol & - & - & - & - & - & - & - & - & - & - & $0.2 \mathrm{~g}$ & $0.4 \mathrm{~g}$ & $0.4 \mathrm{~g}$ \\
\hline Cetyl alcohol & - & - & - & - & - & - & - & - & - & - & - & $0.2 \mathrm{~g}$ & $0.2 \mathrm{~g}$ \\
\hline Stearic acid & - & - & - & - & - & - & - & - & - & - & - & - & $0.3 \mathrm{~g}$ \\
\hline Triethanolamine & - & - & - & - & - & - & - & - & - & - & - & - & $0.1 \mathrm{~g}$ \\
\hline Tween 80 & $0.1 \mathrm{~g}$ & $0.2 \mathrm{~g}$ & $0.3 \mathrm{~g}$ & $0.5 \mathrm{~g}$ & - & $0.1 \mathrm{~g}$ & $0.2 \mathrm{~g}$ & - & - & - & - & - & - \\
\hline Absolute ethanol & $1.2 \mathrm{~g}$ & $1.2 \mathrm{~g}$ & $1.2 \mathrm{~g}$ & $1.2 \mathrm{~g}$ & $1.2 \mathrm{~g}$ & $1.2 \mathrm{~g}$ & $1.2 \mathrm{~g}$ & $1.2 \mathrm{~g}$ & $1.2 \mathrm{~g}$ & $1.2 \mathrm{~g}$ & $1.2 \mathrm{~g}$ & $1.2 \mathrm{~g}$ & $1.2 \mathrm{~g}$ \\
\hline Preservative & $0.1 \mathrm{~mL}$ & $0.1 \mathrm{~mL}$ & $0.1 \mathrm{~mL}$ & $0.1 \mathrm{~mL}$ & $0.1 \mathrm{~mL}$ & $0.1 \mathrm{~mL}$ & $0.1 \mathrm{~mL}$ & $0.1 \mathrm{~mL}$ & $0.1 \mathrm{~mL}$ & $0.1 \mathrm{~mL}$ & $0.1 \mathrm{~mL}$ & $0.1 \mathrm{~mL}$ & $0.1 \mathrm{~mL}$ \\
\hline Purified water & $\begin{array}{l}\text { QS to } \\
9.5 \mathrm{~g}\end{array}$ & $\begin{array}{l}\text { QS to } \\
9.5 \mathrm{~g}\end{array}$ & $\begin{array}{l}\text { QS to } \\
9.5 \mathrm{~g}\end{array}$ & $\begin{array}{l}\text { QS to } \\
9.5 \mathrm{~g}\end{array}$ & $\begin{array}{l}\text { QS to } \\
9.5 \mathrm{~g}\end{array}$ & $\begin{array}{l}\text { QS to } \\
9.5 \mathrm{~g}\end{array}$ & $\begin{array}{l}\text { QS to } \\
9.5 \mathrm{~g}\end{array}$ & $\begin{array}{l}\text { QS to } \\
9.5 \mathrm{~g}\end{array}$ & $\begin{array}{l}\text { QS to } \\
9.5 \mathrm{~g}\end{array}$ & $\begin{array}{l}\text { QS to } \\
9.5 \mathrm{~g}\end{array}$ & $\begin{array}{l}\text { QS to } \\
9.5 \mathrm{~g}\end{array}$ & $\begin{array}{l}\text { QS to } \\
9.5 \mathrm{~g}\end{array}$ & $\begin{array}{l}\text { QS to } \\
9.5 \mathrm{~g}\end{array}$ \\
\hline \multicolumn{14}{|c|}{ In vitro physical properties } \\
\hline Spreadability & 2 & 1 & 1 & 1 & 0 & 0 & 0 & 1 & 1 & 1 & 2 & 2 & 1 \\
\hline Acceptability & $x$ & $\sqrt{ }$ & $\sqrt{ }$ & $\sqrt{ }$ & $x$ & $x$ & $x$ & $\sqrt{ }$ & $\sqrt{ }$ & $\sqrt{ }$ & $x$ & $x$ & $x$ \\
\hline $\begin{array}{l}\text { Gravitational } \\
\text { stability }\end{array}$ & $\sqrt{ }$ & $\sqrt{ }$ & $\sqrt{ }$ & $\sqrt{ }$ & $\sqrt{ }$ & $\sqrt{ }$ & $\sqrt{ }$ & $\sqrt{ }$ & $\sqrt{ }$ & $\sqrt{ }$ & $\sqrt{ }$ & $x$ & $\sqrt{ }$ \\
\hline
\end{tabular}


J Pharm Pharm Sci (www.cspsCanada.org) 18(4) 578 - 599, 2015

Table S9. Formulation ingredients and physical properties of trial formulations (series 2-3).

Series 2-3

\begin{tabular}{|c|c|c|c|c|c|c|c|c|c|c|c|}
\hline \multirow[b]{2}{*}{ Ingredients } & \multicolumn{11}{|c|}{ Formulation number } \\
\hline & 1 & 2 & 3 & 4 & 5 & 6 & 7 & 8 & 9 & 10 & 11 \\
\hline Span 40 & $0.1 \mathrm{~g}$ & $0.2 \mathrm{~g}$ & $0.3 \mathrm{~g}$ & $0.2 \mathrm{~g}$ & $0.3 \mathrm{~g}$ & $0.5 \mathrm{~g}$ & $0.5 \mathrm{~g}$ & $0.5 \mathrm{~g}$ & $0.5 \mathrm{~g}$ & - & - \\
\hline Polychol 15 & $0.5 \mathrm{~g}$ & $0.5 \mathrm{~g}$ & $0.5 \mathrm{~g}$ & $1 \mathrm{~g}$ & $1 \mathrm{~g}$ & $1 \mathrm{~g}$ & $1 \mathrm{~g}$ & $1 \mathrm{~g}$ & $1 \mathrm{~g}$ & - & - \\
\hline Stearyl alcohol & $1.5 \mathrm{~g}$ & $1.2 \mathrm{~g}$ & $1.2 \mathrm{~g}$ & $1.2 \mathrm{~g}$ & $1.2 \mathrm{~g}$ & $1.2 \mathrm{~g}$ & - & - & - & - & - \\
\hline Cremophor EL & $0.2 \mathrm{~g}$ & $0.4 \mathrm{~g}$ & $0.5 \mathrm{~g}$ & - & - & - & - & - & - & $0.3 \mathrm{~g}$ & $0.3 \mathrm{~g}$ \\
\hline Vaseline & - & $0.6 \mathrm{~g}$ & $0.6 \mathrm{~g}$ & $0.6 \mathrm{~g}$ & $0.6 \mathrm{~g}$ & $0.6 \mathrm{~g}$ & $0.6 \mathrm{~g}$ & - & - & - & - \\
\hline Octyldodecanol & - & - & - & - & - & - & $0.5 \mathrm{~g}$ & - & $0.8 \mathrm{~g}$ & - & - \\
\hline Lanolin alcohol & - & - & - & - & - & - & $0.7 \mathrm{~g}$ & $0.4 \mathrm{~g}$ & - & - & - \\
\hline Microcrystalline wax & - & - & - & - & - & - & - & $0.6 \mathrm{~g}$ & $0.6 \mathrm{~g}$ & - & - \\
\hline Isoeicosane & - & - & - & - & - & - & - & $0.8 \mathrm{~g}$ & - & - & - \\
\hline Beeswax & - & - & - & - & - & - & - & - & $0.4 \mathrm{~g}$ & - & - \\
\hline Cetyl alcohol & - & - & - & - & - & - & - & - & - & $0.6 \mathrm{~g}$ & $0.8 \mathrm{~g}$ \\
\hline Span 80 & - & - & - & - & - & - & - & - & - & $0.2 \mathrm{~g}$ & $0.2 \mathrm{~g}$ \\
\hline Polychol 40 & - & - & - & - & - & - & - & - & - & $0.5 \mathrm{~g}$ & $0.5 \mathrm{~g}$ \\
\hline Liquid paraffin & - & - & - & - & - & - & - & - & - & $0.6 \mathrm{~g}$ & - \\
\hline Stearic acid & - & - & - & - & - & - & - & - & - & $0.5 \mathrm{~g}$ & - \\
\hline Triethanolamine & - & - & - & - & - & - & - & - & - & $0.2 \mathrm{~g}$ & - \\
\hline Polawax & - & - & - & - & - & - & - & - & - & - & $1 \mathrm{~g}$ \\
\hline Glycerol & - & - & - & - & - & - & - & - & - & - & $0.5 \mathrm{~g}$ \\
\hline Absolute ethanol & $1.2 \mathrm{~g}$ & $1.2 \mathrm{~g}$ & $1.2 \mathrm{~g}$ & $1.2 \mathrm{~g}$ & $1.2 \mathrm{~g}$ & $1.2 \mathrm{~g}$ & $1.2 \mathrm{~g}$ & $1.2 \mathrm{~g}$ & $1.2 \mathrm{~g}$ & $1.2 \mathrm{~g}$ & $1.2 \mathrm{~g}$ \\
\hline Preservative & $0.1 \mathrm{~mL}$ & $0.1 \mathrm{~mL}$ & $0.1 \mathrm{~mL}$ & $0.1 \mathrm{~mL}$ & $0.1 \mathrm{~mL}$ & $0.1 \mathrm{~mL}$ & $0.1 \mathrm{~mL}$ & $0.1 \mathrm{~mL}$ & $0.1 \mathrm{~mL}$ & $0.1 \mathrm{~mL}$ & $0.1 \mathrm{~mL}$ \\
\hline Purified water & $\begin{array}{l}\text { QS to } \\
9.5 \mathrm{~g} \\
\end{array}$ & $\begin{array}{l}\text { QS to } \\
9.5 \mathrm{~g} \\
\end{array}$ & $\begin{array}{l}\text { QS to } \\
9.5 \mathrm{~g}\end{array}$ & $\begin{array}{l}\text { QS to } \\
9.5 \mathrm{~g} \\
\end{array}$ & $\begin{array}{l}\text { QS to } \\
9.5 \mathrm{~g} \\
\end{array}$ & $\begin{array}{l}\text { QS to } \\
9.5 \mathrm{~g}\end{array}$ & $\begin{array}{l}\text { QS to } \\
9.5 \mathrm{~g} \\
\end{array}$ & $\begin{array}{l}\text { QS to } \\
9.5 \mathrm{~g} \\
\end{array}$ & $\begin{array}{l}\text { QS to } \\
9.5 \mathrm{~g} \\
\end{array}$ & QS to $9.5 \mathrm{~g}$ & $\begin{array}{l}\text { QS to } \\
9.5 \mathrm{~g} \\
\end{array}$ \\
\hline
\end{tabular}


J Pharm Pharm Sci (www.cspsCanada.org) 18(4) 578 - 599, 2015

Table S9 - Series 2-3 (cont.)

\begin{tabular}{|c|c|c|c|c|c|c|c|c|c|c|c|}
\hline & \multicolumn{11}{|c|}{ Formulation number } \\
\hline & 1 & 2 & 3 & 4 & 5 & 6 & 7 & 8 & 9 & 10 & 11 \\
\hline \multicolumn{12}{|c|}{ In vitro physical properties } \\
\hline Spreadability & 2 & 1 & 1 & 1 & 1 & 1 & 1 & 1 & 1 & \multirow{3}{*}{$\begin{array}{l}\text { failed to } \\
\text { form } \\
\text { emulsion }\end{array}$} & 1 \\
\hline Acceptability & $x$ & $\sqrt{ }$ & $\sqrt{ }$ & $\sqrt{ }$ & $\sqrt{ }$ & $\sqrt{ }$ & $\sqrt{ }$ & $\sqrt{ }$ & $\sqrt{ }$ & & $x$ \\
\hline Gravitational stability & $\sqrt{ }$ & $\sqrt{ }$ & $\sqrt{ }$ & $\sqrt{ }$ & $\sqrt{ }$ & $\sqrt{ }$ & $x$ & $x$ & $x$ & & $x$ \\
\hline
\end{tabular}

$\mathrm{QS}=$ quantum sufficiat (sufficient quantity) 